\title{
Fuel Improvement Measures for Particulate Matter Emission Reduction during Corn Cob Combustion
}

\author{
Nataša Dragutinović *(D), Isabel Höfer and Martin Kaltschmitt \\ Institute of Environmental Technology and Energy Economics (IUE), Hamburg University of Technology (TUHH), \\ Eissendorferstraße 40, 21703 Hamburg, Germany; isabel.hoefer@tuhh.de (I.H.); kaltschmitt@tuhh.de (M.K.) \\ * Correspondence: natasa.dragutinovic@tuhh.de; Tel.: +49-40-428-78-2021
}

check for updates

Citation: Dragutinović, N.; Höfer, I.; Kaltschmitt, M. Fuel Improvement Measures for Particulate Matter Emission Reduction during Corn $\mathrm{Cob}$ Combustion. Energies 2021, 14, 4548. https://doi.org/10.3390/en14154548

Academic Editors: Rajender Gupta and Dmitri A. Bulushev

Received: 10 June 2021

Accepted: 23 July 2021

Published: 27 July 2021

Publisher's Note: MDPI stays neutral with regard to jurisdictional claims in published maps and institutional affiliations.

Copyright: (c) 2021 by the authors. Licensee MDPI, Basel, Switzerland. This article is an open access article distributed under the terms and conditions of the Creative Commons Attribution (CC BY) license (https:// creativecommons.org/licenses/by/ $4.0 /)$.

\begin{abstract}
Fuel-related measures and modernization of small-scale combustion units has become the focus of attention in the renewable heat generation sector, as a means to promote local biomass utilization and fuel-flexibility while meeting strict environmental legislative requirements. With the aim to mitigate total particulate matter emissions and ash-associated problems characteristic of crop residue combustion, (1) corn cob pellets (with and without kaolin and binder) as well as (2) fuel blends with wood pellets were combusted in a pellet oven under full load. Results show that additivation or fuel blending (e.g., $50 \mathrm{wt}$. \% wood and $50 \mathrm{wt}$. \% corn cob pellets) reduce total particulate and CO-emissions by 48 to $60 \mathrm{wt}$. \% and 64 to $89 \mathrm{wt}$. \%, respectively, in comparison to baseline emissions from non-additivized corn cob pellets. Kaolin prevented sintering of corn cob ash. However, considerable grate ash entrainment was observed. TPM consists of a "primary network"-polyhedral and spherical particles approximately $1 \mu \mathrm{m}$ in diameter (mainly $\mathrm{KCl}$ ), and a "secondary network" built on top of the primary network, consisting of square-prism-shaped particles of approximately $200 \mathrm{~nm}$ in diameter. $\mathrm{KCl}$ and $\mathrm{K}_{2} \mathrm{SO}_{4}$ are main compounds in particles from corn cob and wood pellet combustion, respectively. Effective measures demonstrated within this study should be complemented with low-cost coarse ash removal systems.
\end{abstract}

Keywords: biomass; corn cob; combustion; additives; kaolin; particulate matter

\section{Introduction}

Bioenergy, as a $\mathrm{CO}_{2}$-neutral renewable energy source, makes up a large share of renewable energy use today; it is expected to remain a significant fuel source in the future with the potential to replace fossil fuels both in the energy sector, as well as in the production of novel materials and biofuels [1,2]. Recent increased demand for wood as a fuel, coupled with an a priori limited supply, is forcing the energy market to consider other affordable herbaceous biomass as alternative solid biofuel source. In rural regions, crop residues (wheat straw, rice straw, corn stover, corn cobs etc.) could prove as such in small-scale units simultaneously promoting energy independence and economic development. Corn residues are of particular interest for energetic utilization due to its energetic potential and the need for adequate biowaste management. Corn is a major crop worldwide and its production has been growing steadily ed from 568 Mio. $t$ in 1994 to 1148 Mio. $t$ in 2018 [3]. However, corn residues have a high ash content and increased concentrations of particulate matter-forming elements such as $\mathrm{K}$ and $\mathrm{Cl}$ [4-6]. It has been shown that total particulate matter (TPM) emissions are positively correlated with the amount of aerosol forming elements in the fuel [7,8]. Increased pollutant emissions and ash-associated problems, e.g., low ash melting temperatures, corrosion, deposition and fouling, make combustion of crop residues very challenging [9-12]. In order to meet national and international climate change adaptation goals by increasing the share of renewables in the heating sector [13], the search for novel approaches and modern technical solutions for environmentally sound solid biomass energetical utilization is further driven by legislation, policies and more strict emission limits [14]. 
Against this background, different approaches to mitigate aforementioned air-pollution from small-scale combustion units have been in the focus of attention recently. Primary measures have been focused on pollution prevention and include fuel-design (fuel-upgrading) measures such as: pelletizing, additives and fuel blending, to lock up these options in an environmentally sound manner by impeding or promoting specific ash transformation reactions [2,15-17].

As a first step in fuel-upgrading, densification of loose lignocellulosic biomass improves the handling, storage, and transport properties [18-20], as well as enabling its use in automated combustion units [21,22]. This in turn can lead to higher efficiencies and reduction in air-borne emissions $[23,24]$.

Another fuel-related measure which can be applied simultaneously with pelletization is additivation. One of the main goals of additivation during crop residue combustion is to bind aerosol-forming elements, mostly alkali, $\mathrm{Cl}, \mathrm{S}$, and $\mathrm{Zn}$, in the grate ash. By doing so, the release of ash forming volatile components into the gas phase can be avoided and the solid-gaseous-particle pathway of particulate matter formation is suppressed [9,25-27]. Another important goal is to facilitate the incorporation of low-temperature melting Kcontaining compounds (silicates) into more temperature stabile species as well as to increase the ash melting point and prevent sintering [28]. In order to be considered as an additive these compounds need to meet specific requirements: high reactivity, high specific surface and porosity, high melting point (temperature stability), no negative influence on the combustion process such as reduction of efficiency or formation of new pollutants, non-toxic, easy to handle, store, and transport, as well as low specific costs [27,29]. Kaolin is an example of Al-silicate-based additive with large surface area which further facilitates sorption of alkali metals into the bottom ash by forming high-temperature stabile compounds (alkali-Al-silicates) $[4,11,28]$. In addition, kaolin has been proven successful during wood biomass combustion in reducing particulate matter emissions [30-34], as well as improving problematic ash melting behavior. Latest research on the application of kaolin has reported PM-emission reduction up to $50 \mathrm{wt}$. \% [16,20,28,30-34].

Production of biomass blends: (1) improves fuel properties of lower-quality fuels, while promoting the use of local, renewable, low-cost and sustainable solid biogenic waste (such as crop residues). Further, its application reduces market pressure for conventional wood biomass as a fuel resource. There have been a number of recent studies investigating biomass blends, such as follows: red canary grass and wood [34], vine and industrial cork residue [35], grape pomace and Pyrenean oak [36], non-woody biomass and wood [37-49], among them straw/grasses and wood [28,38,40,41,45], other crop residues and wood [42-44,47,48], biomass and sludge [44,49], animal manure and lignocellulosic biomass [50]. What they have found is that blending a "primary fuel" (fuel of interest) with another secondary fuel of "higher-quality", could influence particulate matter formation [42,45], secure stabile and efficient boiler operation [44], and prevent sintering (and other unwanted ash-associated effects) [2,43]. Such mixtures seem to show quite a different behavior during the combustion process compared to the mono-substrate, and sometimes even have a synergistic effect [44].

Previous research on fuel engineering has demonstrated that combination of aforementioned measures can be successfully used to reduce particulate matter emissions from different feedstocks $[17,28,42,51-53]$. Existing studies on the topic of herbaceous biomass combustion, fuel blending and the application of additives, ranged from laboratory-scale studies, to pilot- and industrial scale applications and modelling. However, they mostly investigated wheat straw, both experimentally and theoretically. from. Nevertheless, as other researchers on this topic concluded, each biomass requires an individual approach and a specialized solution to reach the desired goals of emission reduction, efficient combustion and the prevention of sintering (in most cases). Each specific feedstock and application (technical design of the combustion unit) requires in-depth research toidentify an optimal mix of primary measures, e.g., optimal fuel blend and additive content for that specific 
purpose [2]. This has not been conducted for corn cob combustion in small-scale units, according to the authors' knowledge.

In the study by [6] PM-emissions were kept in accordance with emission limit values by using secondary flue-gas treatment (multi-cyclone); meaning, secondary flue gas measures had to be applied. This is not cost-efficient in small scale units, which are the subject topic of our investigation. In addition, Ref. [48] investigated combustion of corn stover pellets with lime as additive in a $50 \mathrm{~kW}$ boiler. This measure has not proven effective, i.e., lime was not useful as additive. The difference between aforementioned study and our study is: (1) different fuel—corn cob and corn stover do not posess the same chemical nor physical properties, (literature reference [28]), (2) different combustion technology, end user, and scale (50 kW moving grate boiler versus $8 \mathrm{~kW}$ pellet oven) and (3) different additives (lime versus kaolin). Moreover, Ref. [9] investigated the application of kaolin and calcite as additives for the prevention of corn stover slagging, one of the ash-associated problems during crop residue combustion. However particulate and gaseous emissions were not monitored or evaluated. Furthermore, Ref. [54] performed laboratory-scale investigation of corn stover fixed-bed combustion test rig and investigated the effects of air feeding and ash content on the pollutant emissions; however, it did not consider particulate matter emissions during combustion. Finally, Ref. [47] investigated effects of air feeding and fuel size on the combustion behavior of blends of corn stover and pinewood in a small fixed bed simulated moving grate furnace. Again in this laboratory-scale investigation effects of aforementioned parameters on particulate matter emissions were not considered or evaluated.

None of aforementioned studies investigated the joint application and effects of fuel blending, additivation with kaolin and pelletization during corn cob for combustion in a small-scale unit $(<20 \mathrm{~kW})$. Therefore, the results of this study will bring an original insight into the effectiveness of primary measures (kaolin as additive) in a pellet oven specifically for corn cob combustion. To add, the results could providea cost-effective approach to improve air quality and reduce environmental burden of crop residue combustion in regions where there is no strict legislative regulation on air-borne emissions from smallscale units using alternative fuels. Based on the results of this study modern fuel-upgrading processes at regional and local level can be developed, facilitating the incorporation of alternative solid biogenic fuels in the heat generation sector in an environmentally friendly way. The possibilities for application of such fuels in rural and suburban areas, where individual heating is dominant over district heating, and where such agricultural residues have long been used as fuel unfortunately in old- and inefficient stoves and ovens, will be better evaluated.

Against this background, the overarching goal of this paper is to investigate the joint implementation of different primary measures such as fuel-processing, additivation, and fuel-blending on the process performance during corn cob combustion in a small-scale fixed bed combustion unit, including reduction of total particulate matter (TPM-) emissions, carbon monoxide (CO-) emissions, ash sintering, as well as the overall efficiency. For this purpose, gaseous emissions, total particulate matter (TPM)-emissions and energy efficiency are monitored and measured according to EN 303-5, VDI 2066-1, and ISO 14785 during combustion of corn cobs pellets with and without kaolin (and starch-based binder) and in blends with wood pellets in an $8 \mathrm{~kW}$ state-of-the-art commercially available pellet oven. The solid combustion products grate ash (GA) and total particulate matter (TPM) are further analyzed for elementary composition, micromorphology, and crystalline phases. Emissions are compared with the requirements of EN 303-5 and European Ecodesign directive.

\section{Materials and Methods}

An overview of the investigation procedure is found in Figure 1. Investigation begins with feedstock characterization and processing (pelletizing), as well as investigation of pellet properties. Produced pellets and fuel blends are then combusted in an $8 \mathrm{~kW}$ state-of- 
the art pellet oven, while gaseous and particulate matter emissions are monitored. Finally, grate and particulate matter samples are further analyzed for elementary composition, micromorphology, and crystalline phases in the laboratory.
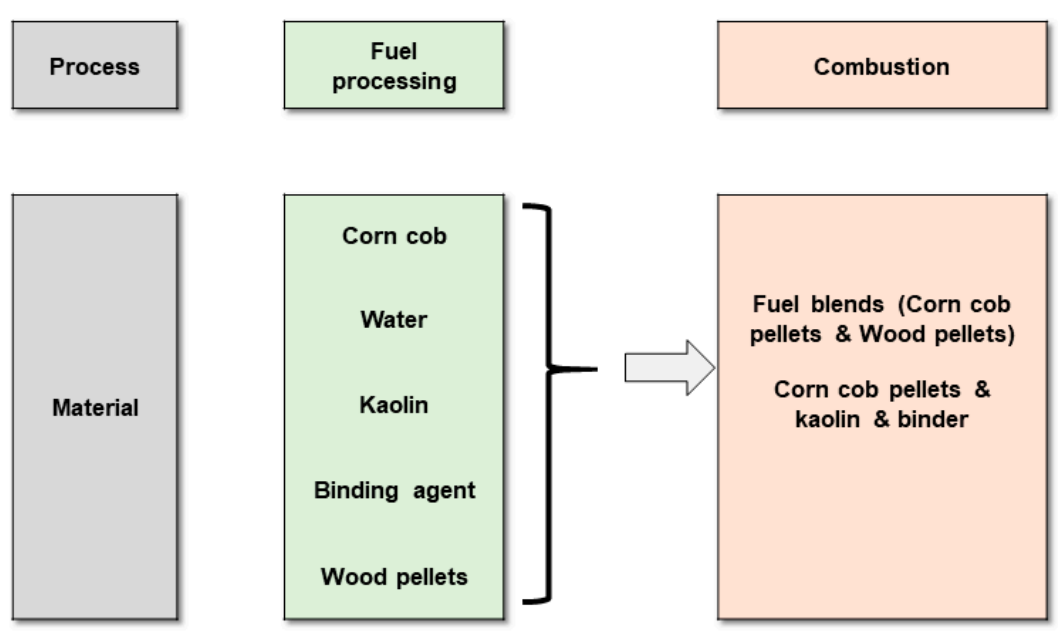

Laboratory analysis
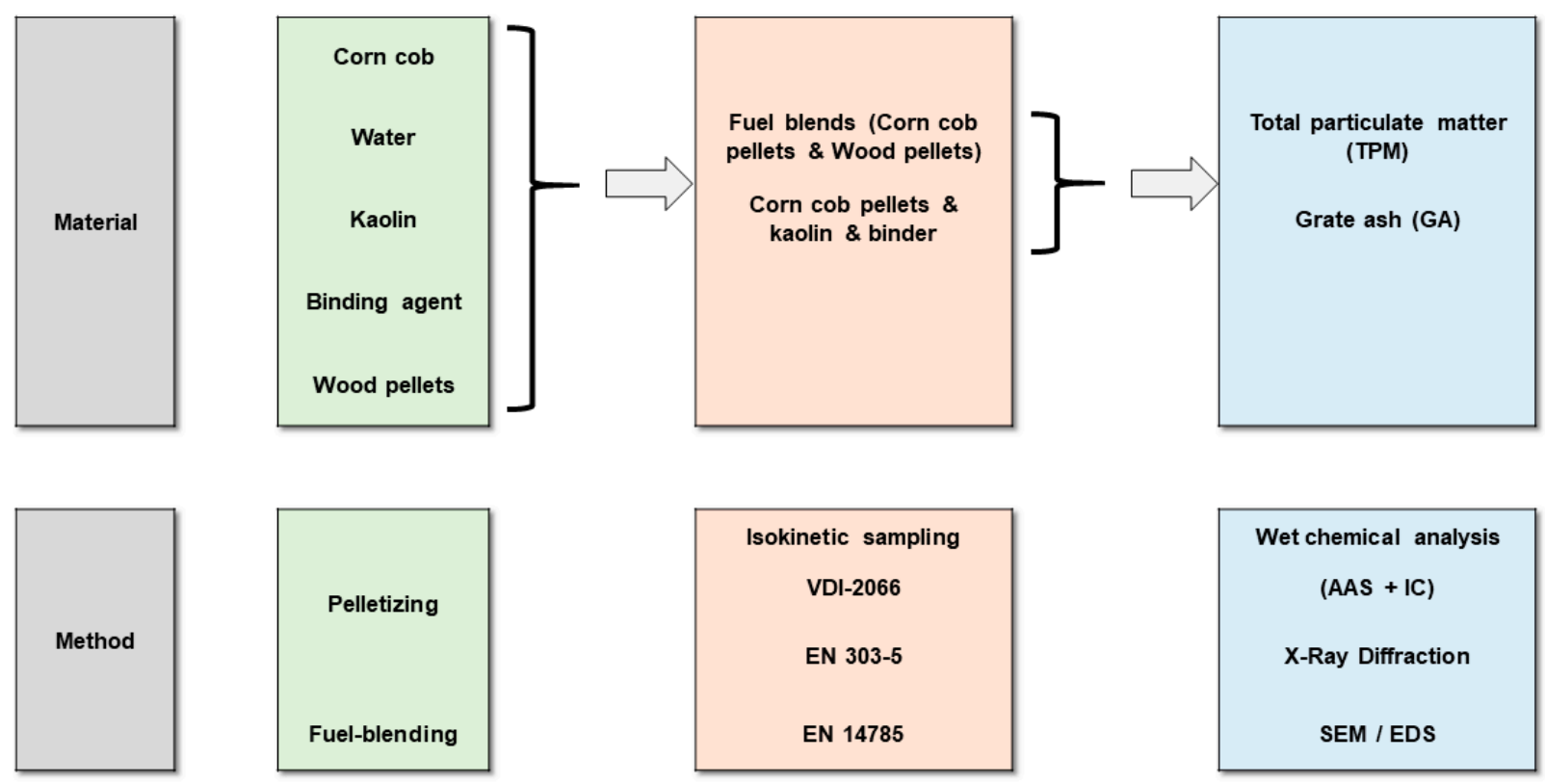

Figure 1. Investigation procedure.

\subsection{Feedstock and Additive}

Corn cob grit (3.8 to $5.0 \mathrm{~mm}$ average diameter) was purchased from a German company and pelletized with and without kaolin (and starch-based binder) at the premises of the Hamburg University of Technology during the course of 2019 and 2020. Detailed study on corn cob pelletizing and properties of corn cob pellets with and without kaolin and starch-based binder addition can be found in another publication [55]. The amount of additive has been chosen based on previous research and available literature [28]. Wood pellets used in this study are commercially available DINPlus certified quality pellets purchased locally in $10 \mathrm{~kg}$ bags.

Table 1 shows the properties of wood and corn cob pellets in comparison with standard requirements for wood (DIN EN ISO 17225-2) and non-woody pellets (DIN EN ISO 17225-6), as well as two types of kaolin (composition of Kaolin A and Kaolin B provided by manufacturers Merck and Dorfner). Kaolin A is a laboratory-grade chemical with high purity, whereas Kaolin B is a commonly found material which is expected to be used in reallife application. Kaolin A is used for all experiments except CCPB, CCPB0.5KAO, and CCPB1.5KAO (where Kaolin B was used). Starch-based binder with starch content 80 wt. \% (RUF) in the amount of $2 \mathrm{wt}$. \% was used to improve the properties of the corn cob pellets with 0 wt. $\%, 0.5$ wt. $\%$ and 1.5 wt. \% Kaolin B. To test the potential effect of starch addition on emissions, total particulate matter and CO-emissions from the combustion of corn cob pellets with and without binder are compared. 
Table 1. Elementary composition of the feedstock and additives $\left({ }^{*} \mathrm{dm}-\right.$ dry matter, ${ }^{* *}$ ar—as received).

\begin{tabular}{|c|c|c|c|c|c|c|c|}
\hline Parameter & Unit & Kaolin A & Kaolin B & $\begin{array}{l}\text { Corn Cob } \\
\text { Pellets }\end{array}$ & $\begin{array}{c}\text { ISO 17225-6 } \\
\text { Class A }\end{array}$ & $\begin{array}{l}\text { Wood } \\
\text { Pellets }\end{array}$ & $\begin{array}{c}\text { ISO 17225-2 } \\
\text { Class A1 }\end{array}$ \\
\hline $\mathrm{C}$ & \multirow{5}{*}{ wt. $\%{ }_{\mathrm{dm}}^{*}$} & - & - & 48.88 & - & 50.15 & - \\
\hline $\mathrm{H}$ & & 1.56 & - & 7.77 & - & 6.49 & - \\
\hline $\mathrm{N}$ & & - & - & 0.11 & $\leq 1.50$ & 0.21 & $\leq 0.30$ \\
\hline$S$ & & - & - & 0.11 & $\leq 1.50$ & $<0.22$ & $\leq 0.04$ \\
\hline $\mathrm{O}$ & & 55.81 & - & 40.23 & - & 42.97 & - \\
\hline $\mathrm{K} / \mathrm{K}_{2} \mathrm{O}$ & \multirow{8}{*}{$\mathrm{g} / \mathrm{kg}_{\mathrm{dm}}$} & - & 0.02 & 7.66 & - & 0.58 & - \\
\hline $\mathrm{Na} / \mathrm{Na}_{2} \mathrm{O}$ & & - & 0.19 & $<0.06$ & - & $<0.20$ & - \\
\hline $\mathrm{P} / \mathrm{P}_{2} \mathrm{O}_{5}$ & & - & 0.18 & 0.19 & - & $<0.13$ & - \\
\hline $\mathrm{Mg} / \mathrm{MgO}$ & & - & 0.01 & 0.19 & - & 0.16 & - \\
\hline $\mathrm{Ca} / \mathrm{CaO}$ & & - & $<0.01$ & 0.06 & - & 0.76 & - \\
\hline $\mathrm{Al} / \mathrm{Al}_{2} \mathrm{O}_{3}$ & & 20.94 & 37.50 & $<0.01$ & - & 0.03 & - \\
\hline $\mathrm{Cl}$ & & - & - & 3.67 & - & $<0.50$ & - \\
\hline $\mathrm{Si} / \mathrm{SiO}_{2}$ & & 21.70 & 44.60 & 0.19 & - & $<0.20$ & - \\
\hline $\mathrm{Zn}$ & \multirow{5}{*}{$\mathrm{mg} / \mathrm{kg}_{\mathrm{dm}}$} & - & - & 14.00 & - & 9.00 & - \\
\hline $\mathrm{Cu}$ & & - & - & 4.70 & - & 5.50 & - \\
\hline $\mathrm{Cd}$ & & - & - & $<0.20$ & - & $<0.40$ & - \\
\hline $\mathrm{Pb}$ & & - & - & $<0.50$ & - & $<1.00$ & - \\
\hline $\mathrm{Hg}$ & & - & - & - & - & $<1.00$ & - \\
\hline Ash content & wt. $\%_{\mathrm{dm}} *$ & $\leq 15.00$ & 14.30 & 1.83 & $\leq 6.00$ & 0.54 & $\leq 0.70$ \\
\hline Moisture content & wt. \%ar $* *$ & - & 10.00 & 9.97 & $\overline{<} 12.00$ & 6.97 & $\leq 10.00$ \\
\hline Lower heating value (LHV) & $\mathrm{MJ} / \mathrm{kg}_{\mathrm{ar}}$ & - & - & 15.48 & $\geq 14.50$ & 17.51 & $\geq 16.50$ \\
\hline Mechanical durability & wt. \% & - & - & 95.87 & $\geq 97.50$ & 97.10 & $\geq 97.50$ \\
\hline Bulk density & $\mathrm{kg} / \mathrm{m}^{3}$ & - & - & 659.00 & $\geq 600.00$ & 608.00 & $\geq 600.00$ \\
\hline
\end{tabular}

\subsection{Experimental Setup}

Investigation begins with the fuel processing (Figure 1). Before producing cob pellets in line with ISO 17225-6 quality standard (Table 1), corn cob grit was mixed with water, kaolin, and starch-based binding agent (in some cases, see Section 2.1) and conditioned in closed plastic containers for $24 \mathrm{~h}$ (for more details see [55]).

Fuel-processing is followed by the investigation of the effects of primary measures on PM-emissions, ash melting behavior, and energy performance during combustion. With this aim, following fuels are prepared (Table 2):

- $\quad$ Fuel blends made of corn cob pellets (no additive no binder) with wood pellets in specific ratios, represented by WP, $12.5 \mathrm{CCP}$ (e.g., $12.5 \mathrm{wt}$ \% $\%$ or $1 / 8$ of corn cob pellets in the fuel blend), $25 \mathrm{CCP}, 50 \mathrm{CCP}$, and CCP. This fuel group should asses the effect of fuel blending as a primary fuel-related measure.

- Corn cob pellets with and without kaolin (and starch-based binder), which are represented by fuels CCP, ССРB, СCPB0.5KAO, ССР1KAO, CCPB1.5KAO, and CCP2KAO. Fuels $\mathrm{CCPB}, \mathrm{CCPB} 0.5 \mathrm{KAO}$, and CCPB1.5KAO are prepared with $2 \mathrm{wt}$. \% starch-based binder and Kaolin B, whereas all other corn cob pellets are produced without the binder (additivized pellets) with Kaolin A. This fuel group should assess the effect of additivation and pelletizing as primary fuel-related measures.

Table 2. Experimental list.

\begin{tabular}{|c|c|}
\hline Fuel & Abbreviation \\
\hline Wood pellets & WP \\
\hline 12.5 wt. $\%$ corn cob pellets and 87.5 wt. $\%$ wood pellets & $12.5 \mathrm{CCP}$ \\
\hline 25 wt. \% corn cob pellets and 75 wt. \% wood pellets & $25 \mathrm{CCP}$ \\
\hline $50 \mathrm{wt}$ \% corn cob pellets and $50 \mathrm{wt}$. \% wood pellets & $50 C C P$ \\
\hline Corn cob pellets & $\mathrm{CCP}$ \\
\hline Corn cob pellets with 2 wt. \% binder & $\mathrm{CCPB}$ \\
\hline Corn cob pellets with 0.5 wt. \% kaolin B and 2 wt. \% binder & ССРВ0.5KAO \\
\hline Corn cob pellets with 1 wt. \% kaolin A & ССР1KAO \\
\hline Corn cob pellets with $1.5 \mathrm{wt}$ \% kaolin B and $2 \mathrm{wt}$. \% binder & ССРB1.5KAO \\
\hline Corn cob pellets with 2 wt. \% kaolin A & CCP2KAO \\
\hline
\end{tabular}


Experimental list including abbreviations is found in Table 2. All experiments were conducted in duplicates, except ССРВ, ССРB0.5KAO, and ССРB1.5KAO which were performed once.

Combustion experiments were performed in line with DIN EN ISO 303-5 under full load in a pellet oven Polly 2.0 (Austrotherm; $8.3 \mathrm{~kW}$ installed thermal capacity), which was integrated into the test stand at TUH's technical centre (Figure 2). Although the pellet oven was designed for combustion of DINPlus certified wood pellets, it came equipped with a hinged-grate, which enabled combustion of agropellets and pellet blends. Fuel is entering the combustion chamber via a top-feed system, while combustion air is distributed from the bottom up through the grate (both automatically controlled). Sintering and ash agglomeration is prevented through occasional activation of the hinged grate (removing the ash into a separate container), and through hourly chamber cleaning with clean air. The following operating settings are used in all experiments: (1) full load, (2) medium pellet quality 2 (1-best, 3-lowest quality pellets). Each experiment lasted approximately $6 \mathrm{~h}$. Gaseous and particulate matter emissions were measured during stationary combustion ( $2 \mathrm{~h}$ after ignition).

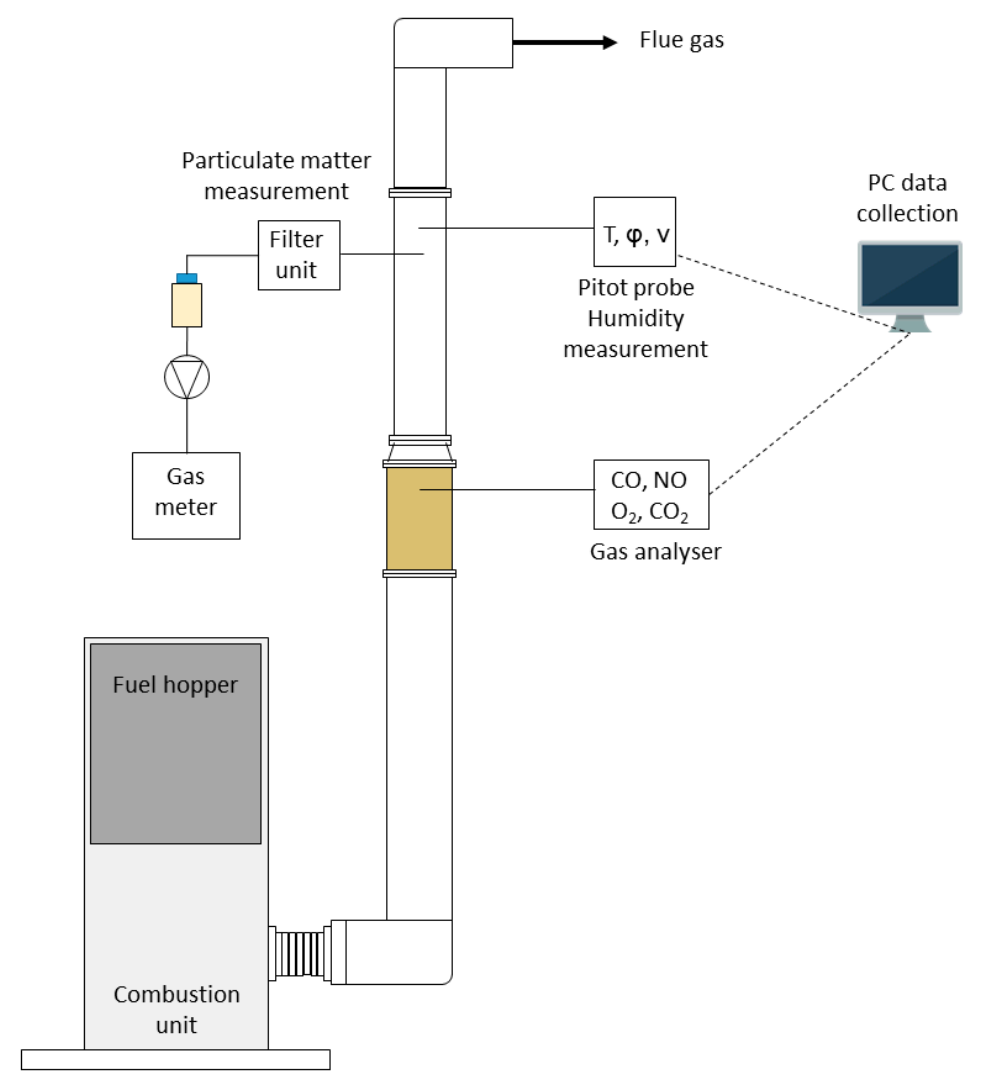

Figure 2. Schematic of the test stand.

\subsection{Measurement and Analysis Methods}

Gaseous emissions were continuously measured and total particulate matter discontinuously sampled during stationary combustion (minimum $2 \mathrm{~h}$ after ignition) and only in between hourly cleaning intervals. After each experiment solid combustion products (grate ash, (GA) and total particulate matter (TPM)) were sampled and further analysed in the laboratory, and energy performance was calculated. Applied methods will be described in this section.

Energy performance. At the beginning of each experiment fuel was prepared by sieving with a $4 \mathrm{~mm}$ square mesh sieve (Retsch), weighed with $1 \mathrm{~g}$ precision scale (OHAUSI-10) and loaded in the fuel hopper ( $25 \mathrm{~kg}$ capacity). After each experiment, leftover fuel was 
collected and weighed. The difference in mass (fuel consumption) is used for calculating the energy efficiency (DIN EN ISO 14785).

Gaseous emissions. During combustion, gaseous products are passing above the grate directly into the flue gas duct and chimney. Here, the gaseous and total particulate matter (TPM) emissions are measured (Figure 2). Flue gas temperature, humidity and velocity are monitored using a Pitot tube and differential pressure manometer with hygrometer (Testo $440 \mathrm{dp})$. Gaseous emissions $\left(\mathrm{CO}_{2}, \mathrm{CO}, \mathrm{NO}_{\mathrm{x}}, \mathrm{H}_{2}\right.$, and $\left.\mathrm{O}_{2}\right)$ are continuously measured using gas analyser (Wöhler A 550) in 10 s intervals. Excess air was calculated from volumetric concentrations of $\mathrm{O}_{2}$ and $\mathrm{CO}$ in the dry flue gas (vol. \%) [56] according to Equation (1).

$$
\lambda=\frac{21}{21-\mathrm{O}_{2}-\mathrm{CO}}
$$

Total particulate matter (TPM). Particulates are discontinuously sampled according to VDI 2066-1 iso-kinetic method using a titanium sampling probe with heated filter unit (Paul Göthe). TPM, as well as gaseous emissions, were sampled in between hourly cleaning intervals. Three TPM measurements, each with a sampling duration of 5 to $15 \mathrm{~min}$ (depending on the pressure drop), were evenly distributed over duration of the experiment. Before the measurement quartz filters (Macherey-Nagel QF-10, diam. $4.5 \mathrm{~cm}$ ), plane filter holders and cartridge filter are conditioned at $160^{\circ} \mathrm{C}$ for $1 \mathrm{~h}$ and cooled down in the desiccator for at least $8 \mathrm{~h}$. Three conditioned filters are used for measurements whereas an additional one is used for blank value determination (error). The filter unit is equipped with a titanium nozzle and probe, enabling iso-kinetic sampling of the flue gas. During sampling, the unit is heated to $160^{\circ} \mathrm{C}$ in order to maintain approximately the same temperature as in flue gas and to prevent any condensation of the gaseous species. After, the filter unit sampling train contains a silica gel bottle to remove the moisture from the sampled flue gas and a pump (Carpanelli) with a gas meter (GMT BK-G4T). During TPM sampling, volumetric flow was kept constant by regulating the vacuum pump flow. The volumetric flow of the sampled gas at the gas meter is calculated based on actual conditions during the combustion experiment-temperatures at the sampling point (filter) and at the gas meter, pressures at both points, and humidity at both mentioned points, according to VDI 2066-1. The sampling plane filters (with sampled TPM) and holders were then heated at $160{ }^{\circ} \mathrm{C}$ for $1 \mathrm{~h}$, kept in the desiccator for $8 \mathrm{~h}$ and weighed using analytical scale (Sartorius R300S).

Laboratory analysis of solid combustion products. After each combustion experiment, samples of grate ash (GA) and particulate matter (TPM) are collected and analyzed. After crushing and homogenizing the GA samples using mortar and pestle, crystalline phases were investigated using powder X-ray Diffraction (Siemens Diffractometer 5000). Both GA and TPM were analyzed for elementary composition using wet chemical analysis (for a detailed description of the sample preparation and analysis see [28]). Selected samples of TPM were coated with $8 \mathrm{~nm}$ gold layer to improve conductivity and analyzed by Scanning Electron Microscope (SEM) and Energy-Dispersive X-ray Spectroscopy (EDS) analysis (Zeiss Supra 55 VP FEG-SEM with Variable Pressure Mode (VP-Mode)).

\section{Results and Discussion}

The effects of applied primary measures on the overall combustion performance will be presented and discussed in the first section, followed by the evaluation of the effects of primary measures on ash sintering. Finally, the emissions and composition of solid combustion residues will be comprehensively analyzed, focusing on $\mathrm{CO}$ - and TPM-emissions and behavior of major ash-forming species.

\subsection{Performance Indicators}

Results. Combustion performance indicators are presented in Table 3 (means were calculated based on values recorded during TPM sampling intervals). All pollutant concentrations are with regards to standard conditions ( $273 \mathrm{~K}$ and 1 bar) and $10 \mathrm{vol} . \% \mathrm{O}_{2}$, as stipulated by EN 303-5 and EcoDesign Directive. Fuel consumption ranges between 
1.2 and $2.0 \mathrm{~kg} / \mathrm{h}$, while efficiency values above $91 \%$ are calculated across the experimental series, meeting standard requirements. However, excess air coefficient is higher than 2 in all cases (with maximum at 3.1).

Table 3. Performance indicators and emissions (for list of fuel names and abbreviations see Table 2).

\begin{tabular}{cccccccc}
\hline Fuel & $\begin{array}{c}\text { Fuel } \\
\text { Consumption }\end{array}$ & $\begin{array}{c}\text { Efficiency } \\
(\mathbf{\eta})\end{array}$ & $\begin{array}{c}\text { Excess Air } \\
(\boldsymbol{\lambda})\end{array}$ & $\mathbf{O}_{\mathbf{2}}$ & $\mathbf{N O}_{\mathbf{x}}$ & $\mathbf{C O}$ & $\mathbf{T P M}$ \\
\hline $\mathbf{k g} / \mathbf{h}$ & $\mathbf{\%}$ & - & $\begin{array}{c}\mathbf{v o l .} \\
\mathbf{\%}\end{array}$ & & $\mathbf{m g} / \mathbf{m}^{\mathbf{3}}$ & \\
\hline WP & 1.3 & 92.5 & 2.6 & 13.0 & 152 & 241 & 39 \\
12.5CCP & 1.4 & 93.0 & 2.5 & 12.7 & 157 & 342 & 88 \\
25CCP & 1.3 & 92.9 & 2.5 & 12.7 & 165 & 538 & 120 \\
50CCP & 1.2 & 93.0 & 2.3 & 12.0 & 160 & 725 & 184 \\
CCP & 1.8 & 92.2 & 2.3 & 11.7 & 170 & 2040 & 463 \\
CCPB & 2.0 & 90.5 & 3.1 & 13.9 & 163 & 2434 & 609 \\
CCPB0.5KAO & 1.8 & 90.3 & 2.8 & 13.5 & 149 & 2236 & 559 \\
CCP1KAO & 1.7 & 92.7 & 2.2 & 11.2 & 176 & 873 & 358 \\
CCPB1.5KAO & 1.9 & 93.0 & 2.2 & 11.6 & 161 & 357 & 317 \\
CCP2 KAO & 1.8 & 91.2 & 2.8 & 13.1 & 171 & 920 & 538 \\
\hline EN 303-5 class 3 & - & $>89.0$ & - & 10.0 & - & $<3000$ & $<150$ \\
EN 303-5 class 4 & - & $>83.0$ & - & 10.0 & - & $<1000$ & $<60$ \\
EN 303-5 class 5 & - & $>75.0$ & - & 10.0 & - & $<500$ & $<40$ \\
EN 14785 & - & $>75.0$ & - & 10.0 & - & $<500$ & - \\
EcoDesign & - & $\geq 77.0$ & - & 10.0 & $<200$ & $<500$ & $<40$ \\
\hline
\end{tabular}

Discussion. Higher consumption of corn cobs during combustion (in comparison with wood pellet consumption) can be explained by lower LHV of corn cob. Excess air in the range from 2.3 to 3 indicates incomplete combustion due to combustion air overfeeding. Excessive air in the flue gas could be the result of non-uniform distribution of combustion air, varying geometrical, chemical, and physico-mechanical pellet properties, short residence time etc. [57]. In addition, lower heating values and moisture might influence the combustion performance due to lower energy density of corn cob pellets. However, since efficiency values from all experiments are higher than $90 \%$, neither the aforementioned pellet properties, nor the additivation and addition of binder seem to negatively affect the combustion efficiency. Lower values of mechanical durability (higher content of fines) in combination with higher ash content (additivated and non-additivated corn cob pellets) are directly correlated with increased TPM-emissions from the combustion of corn cob pellets, which will be discussed in detail in the following sections. Our results are in line with findings by [23], where combustion efficiency was reported to range from 83 to $89 \%$ when using maize as a fuel, and in general efficiency varied between 79 and $91 \%$ when combustion agricultural residues in a $15 \mathrm{~kW}$ pellet oven, and higher than those reported by [58,59] (64\% and approximately $75 \%)$. High excess air values during smallscale biomass combustion was also reported in a study by [60], where excess air value ranging from 2.5 to 7.5 from wood pellet ovens were calculated. These results highlight the need for more flexible combustion units which allow variation of operational parameters to adjust to different fuel properties of agro-pellets. This could be achieved by more flexible fuel and air feeding control.

\subsection{Ash Sintering}

Results. Experiments were conducted without interruptions. No issues with the air-feeding through the grate or with the ash removal system have been observed. Some sintering occurred during combustion of non-additivized corn cob pellets, but not severe enough to cause issues within the 6-h experiment (Figure 3a). Kaolin prevented grate ash sintering, which remained powdery. However, during combustion of additivized pellets we observed significant grate ash entrainment into the flue gas followed by deposition in 
the combustion chamber and chimney (Figure 3c). This was further exacerbated during cleaning intervals.

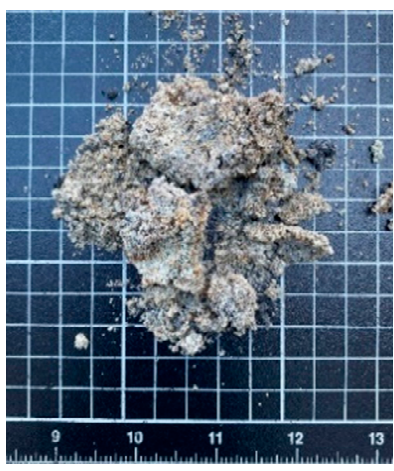

(a)

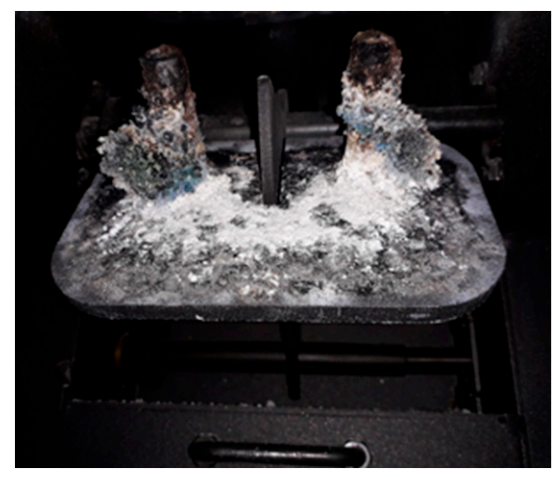

(b)

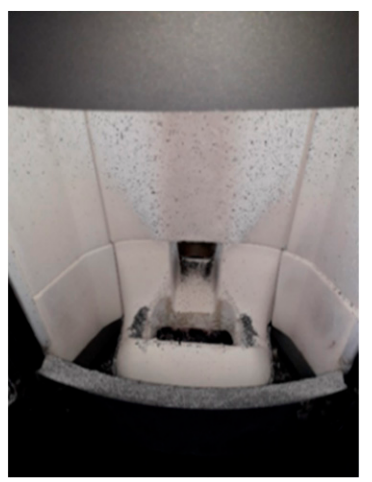

(c)

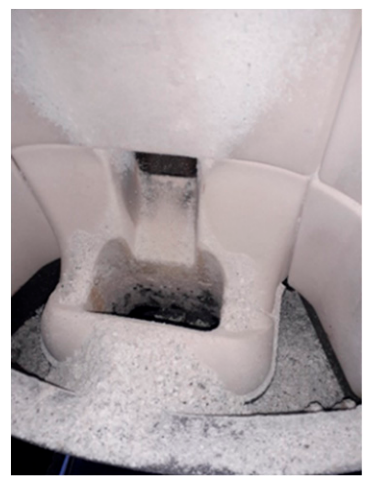

(d)

Figure 3. Photographs of (a) grate ash from non-additivized corn cob pellet combustion (CCP); (b) hinged-grate after non-additivized corn cob pellet combustion (CCP); (c) combustion chamber after experiment with non-additivized corn cob pellets (CCP); (d) combustion chamber after combustion with 1.5 wt. \% kaolin (CCPB0.5KAO).

Discussion. Although no sintering was recorded during the experiment with nonadditivized corn cob pellet (Figure $3 \mathrm{a}$ ), such issues cannot be excluded during long-term oven operation, and is expected to occur in real-life conditions (Figure 3b). A clear tendency toward agglomeration is evident from the photographs and known from previous studies [28], The characteristic greenish ash color and some weak agglomerations in the ash were indeed present [55]. Ref. [61] reported a beginning of the melting of corn cob ash at $600{ }^{\circ} \mathrm{C}$ and an inhomogeneous nature of the ash at this temperature. In order to extend the operational life, avoid process disruptions and mitigate CO- and TPM-emissions, the application of kaolin is effective. However, due to considerable entrainment of grate ash with economic considerations in mind, additivation should be kept at minimum. Exacerbation of ash entrainment with kaolin addition can be observed by comparing Figure $3 c, d$. Entrainment of ash with kaolin had been previously reported as an issue during boiler operation [53,62].

\subsection{Emissions}

Mean values of CO- and TPM-emissions, main pollutants from small-scale biomass combustion, are presented and discussed in the following section.

\subsubsection{CO-Emissions}

Results. Mean CO-emission (Figure 4) is positively correlated with the share of corn cob pellets in fuel blend (Pearson correlation coefficient 0.93 ) and is 10 times higher from the combustion of corn cob pellets than from the combustion of wood pellets. Beside high emission values, strong variations were recorded throughout the experiment (Figure 5). Highest reduction in CO-emission of approximately $89 \mathrm{wt}$. \% has been observed with the addition of $1.5 \mathrm{wt}$ \% of kaolin (and binder) to corn cob pellets, in comparison with $\mathrm{CO}-\mathrm{emissions}$ from corn cob pellet (and binder, $\mathrm{CCPB}$ ) combustion. The addition of just $1 \mathrm{wt}$. \% kaolin (no binder) an approximately $57 \mathrm{wt}$. \% reduction has been measured, in comparison with CO-emissions from pure corn cob pellet (CCP) combustion. 


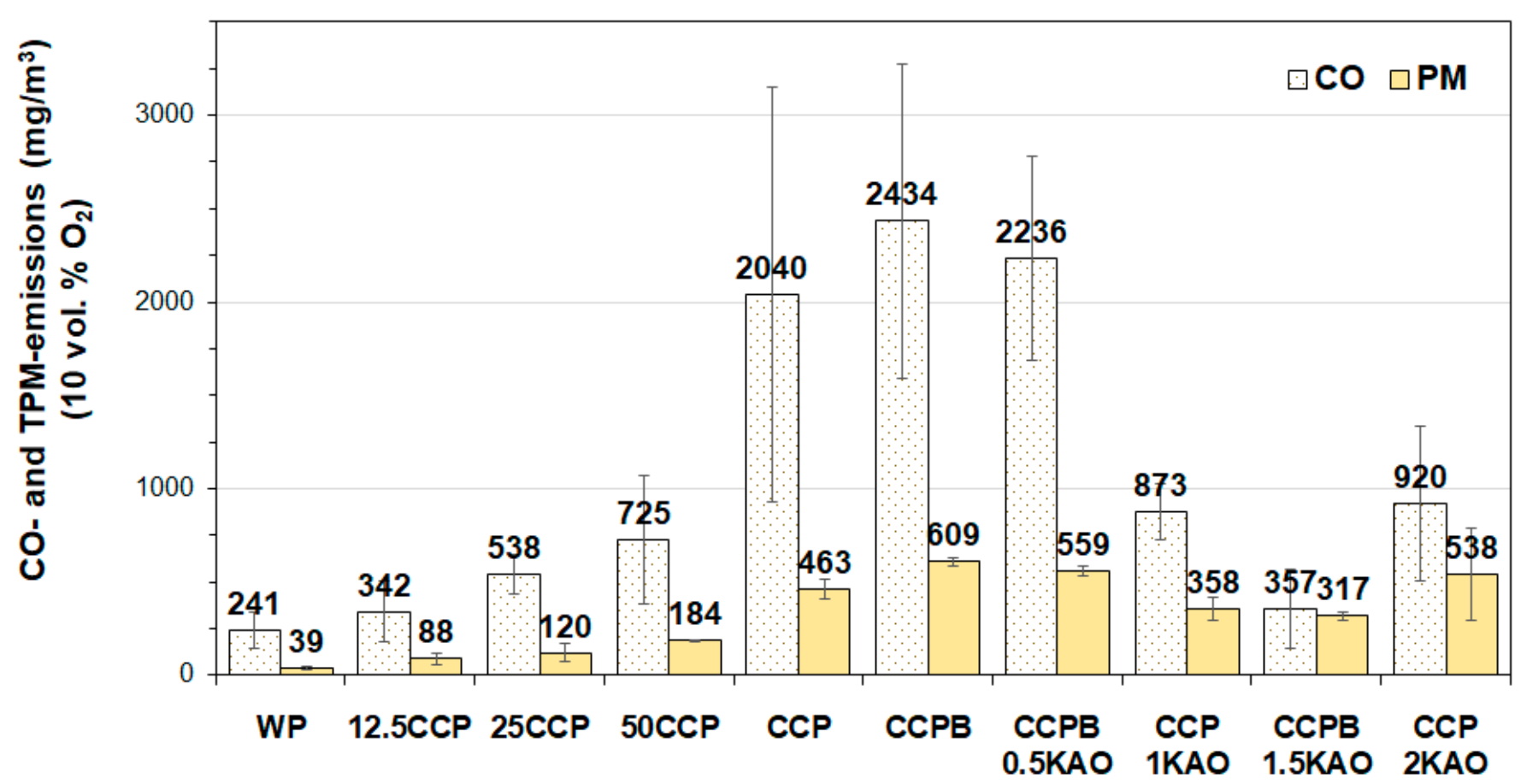

Figure 4. Carbon monoxide (CO-) and total particulate matter (TPM-) emissions (for experimental list see Table 2).

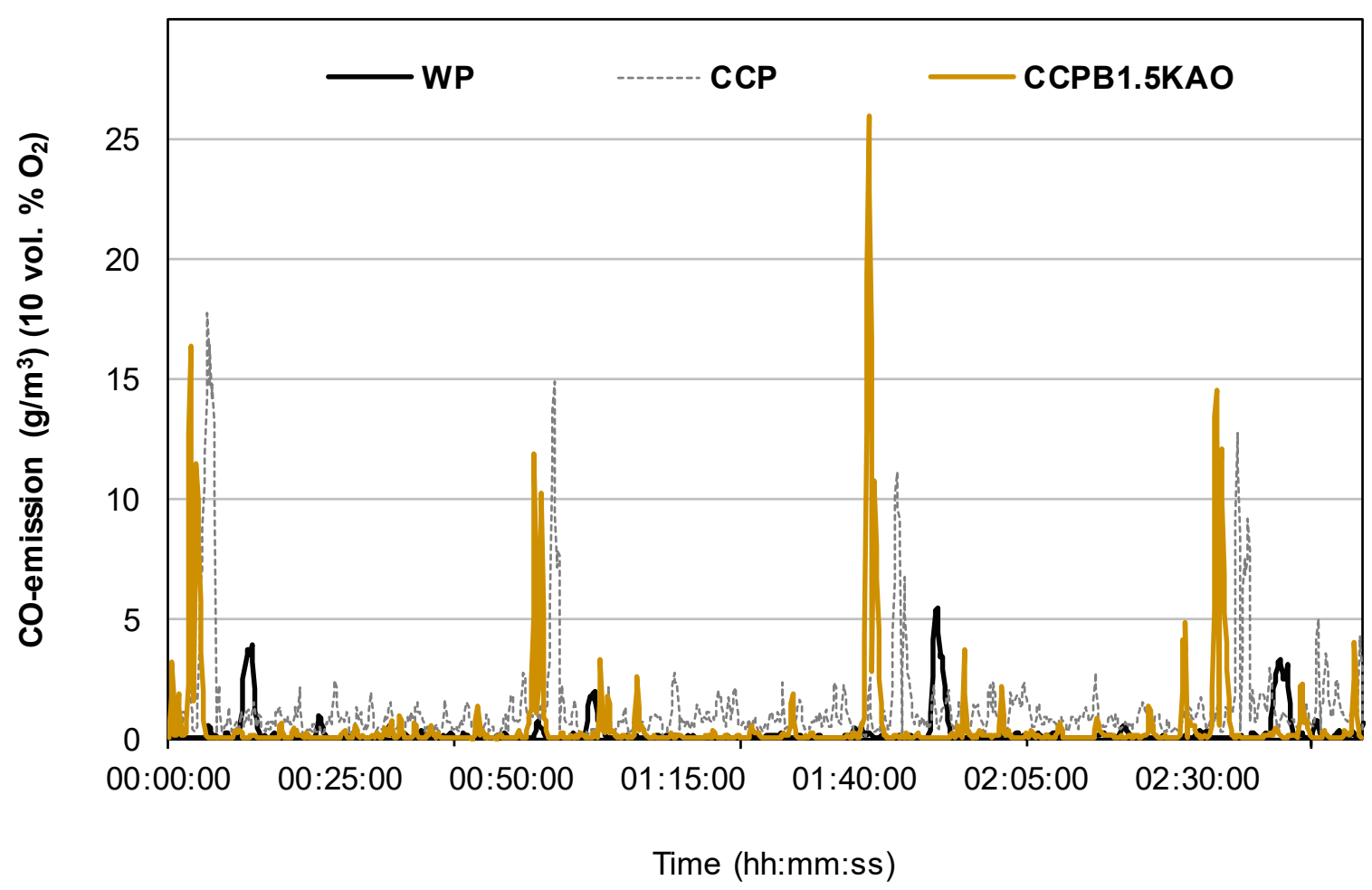

Figure 5. Carbon monoxide (CO-)emission variation during combustion (for experimental list see Table 2).

Discussion. Clear difference can be seen in CO-emission profiles for wood pellets and corn cob pellets with kaolin and binder (Figure 5). During combustion of wood pellets consistently low CO-emissions were measured, except during hourly cleaning intervals. On the other hand, stark variations and peaks were present during combustion of corn cob pellets during the entire process. On the other hand, combustion experiment with corn cob pellets with the lowest CO-emissions (CCPB1.5KAO) is clearly differentiated 
from original corn cob pellet combustion, with a CO-profile more resembling that of wood pellet combustion.

There is considerable room for improvement regarding CO-emission reduction (i.e., to reach a full oxidation of all fuel components), since excessive air feeding probably caused cooling in the combustion chamber, as indicated by relatively high values of excess air coefficient. These $\mathrm{CO}$ emissions might result also from poor mixing of unburnt components with combustion air and/or too short residence time. Presence of unburned volatiles in the grate ash supports this (see Section 3.4.1). Fuel blending with wood pellets has shown to be effective in reducing CO-emissions from agro-pellet combustion. Moreover, use of technical-grade kaolin and starch do not negatively affect combustion and associated emissions. Based on mean CO-emissions, additivation with $1.5 \mathrm{wt}$. \% kaolin could replace approximately $75 \mathrm{wt}$. \% wood pellets in the fuel blends, reducing the amount of wood resources required to achieve CO-emission reduction.

Previous studies on crop residue combustion reported average $\mathrm{CO}$-emission values from $15.6 \mathrm{mg} / \mathrm{m}^{3}\left(13\right.$ vol. $\left.\% \mathrm{O}_{2}\right)$ up to approximately $2000 \mathrm{mg} / \mathrm{m}^{3}$. Studies on maize and triticale pellet combustion by $[6,63]$ reported average $\mathrm{CO}$ values of just $15.6 \mathrm{mg} / \mathrm{Nm}^{3}$ (related to 13 vol. $\% \mathrm{O}_{2}$ and dry flue gas) and $78 \mathrm{mg} / \mathrm{Nm}^{3}\left(13\right.$ vol. $\left.\% \mathrm{O}_{2}\right)$, respectively, which are lower than CO-emissions from our study. On the other hand, studies by $[59,64]$ reported $\mathrm{CO}$ emissions from small-scale wheat straw pellet and hay briquettes combustion to be approximately $500 \mathrm{mg} / \mathrm{Nm}^{3}$ and $2000 \mathrm{mg} / \mathrm{Nm}^{3}$, respectively, more in accordance with our results. In general $\mathrm{CO}$ emission values of $>1000 \mathrm{mg} / \mathrm{Nm}^{3}$ are characteristic of manual heating units. On a input energy basis, Refs. $[23,65]$ reported average CO emissions of approximately $100 \mathrm{mg} / \mathrm{MJ}$ and $5.2 \mathrm{~g} / \mathrm{kg}$ during the combustion of maize and corn stalk pellets, respectively, both being lower than $640 \mathrm{mg} / \mathrm{MJ}$ and $9.8 \mathrm{~g} / \mathrm{kg} \mathrm{CO}$ emissions from our study. This again highlights the aforementioned need for more flexible combustion systems, or systems designed for agropellet combustion which will enable more complete combustion.

Kaolin has previously been proven effective in reducing CO-emission during combustion of wood fuels $[30,33,45,62]$. Recently its application in combustion of herbaceous biomass and crop residues has been in the focus of attention [62]. Refs. [30,62] reported a $50 \%$ and $92 \%$ decrease in CO-emissions from small-scale wood and poplar pellet combustion with kaolin, respectively. Furthermore, Ref. [37] reported a decrease in $\mathrm{CO}$ emissions from combustion of mixed pellets (straw and peat) in a $60 \mathrm{~kW}$ moving grate burner after addition of kaolin. Even though the reason for CO-emission reduction with kaolin is still not fully clear, one explanation could be the catalytic effect of alkali metals with kaolin $[30,66,67]$. Increase of specific surface and porosity of kaolin after calcination [68] - heating and transformation into meta-kaolinite $>585^{\circ} \mathrm{C}$, facilitates oxidation of organic residues present in the ash, as well as ash-forming elements. However, further research is needed. Mixing kaolin with feedstock before pelletization seems to be the appropriate way of applying additives in pellet combustion, supported by findings from [62], which recorded reduction of PM-emissions when kaolin was added to the feedstock before palletization but an increase in emissions when kaolin was introduced to the pellets later in the combustion chamber.

Based on aforementioned results, it can be concluded that the synergy of (1) modern combustion systems - equipped with control and active ash removal systems and (2) fuelrelated measures such as additivation and fuel processing (pelletizing), can considerably improve combustion efficiency thereby facilitating emission reduction. This was illustrated by lower CO-emission values from combustion of additivized and pelletized crop residue in a modern pellet oven.

\subsubsection{Total Particulate Matter Emissions}

Results. Analogue to CO-emissions, there is a strong correlation between TPMemissions and corn cob share in the fuel blend (Pearson coef. 0.98). Mean TPM-emission from corn cob pellet combustion is 11 times higher than that from wood pellet combustion 
(Figure 4). Reductions of approximately $48 \mathrm{wt}$. \% and $36 \mathrm{wt}$. \% were measured with the addition of $1.5 \mathrm{wt}$. \% of kaolin (with binder) and $1 \mathrm{wt}$. \% kaolin (without binder) respectively, in comparison with TPM-emissions from combustion of non-additivized corn cob pellets with and without binder, respectively.

Discussion. Based on our results, only combustion of up to $25 \mathrm{wt}$. \% corn cob pellets in fuel blends would be in line with regulatory requirements. This allows for a strongly limited fuel flexibility within the heating period and does not allow an independence from the wood pellet market. Increased TPM-emissions from corn cob pellet combustion could be traced back to lower mechanical durability, leading to increased fines content generation from fuel manipulation and feeding, in combination with increased fuel ash content $[4,69,70]$. Observed reductions with kaolin are in line with respective results on CO-emissions. We observed no negative effects of applying technical-grade kaolin and starch on TPM-emissions.

The largest reduction in TPM-emissions (achieved with $1.5 \mathrm{wt}$. \% kaolin) is not in line with stoichiometric calculations [53], according to which $2.8 \mathrm{wt}$. \% kaolin should be added for complete $\mathrm{K}$ sorption in the grate ash (based on $\mathrm{K}$ and $\mathrm{Al}$ content in biomass and kaolin). Increased amount of ash in a relatively small combustion chamber could have prevented full burnout, as suggested by the increase in CO-emissions with 2 wt. \% kaolin in comparison with CO-emission with lower amounts of kaolin (consequently also lower amount of ash). It was shown in a previous lab-scale study that assessment of optimal additive content based solely on stoichiometric considerations (of alkali binding using kaolin) is not advisable [71]. Furthermore, it is known from experience in this study and from previous studies $[53,62]$ that increased contents of kaolin lead to grate ash entrainment. This could be another reason for increased TPM-emissions with 2 wt. \% kaolin, even though this amount is closer to the theoretically optimal amount of $2.8 \mathrm{wt}$. \%. If additional real-scale related parameters are considered, such as loss of additive during and after palletization and combustion technology (fuel- and air-feeding), stoichiometrically optimal additive content could serve as a starting point. However, each case (fuel and combustion technology) should be individually analyzed. With total particulate matter emission reduction as the main goal and with experimental results in mind, the optimal share of kaolin would be between $1 \mathrm{wt}$. \% and $2 \mathrm{wt}$. \%, possibly $1.5 \mathrm{wt}$. \%. However, detailed investigation for the verification of the attained results is needed.

In comparison with our results, Refs. [6,59] reported lower values of PM-emissions, $92 \mathrm{mg} / \mathrm{Nm}^{3}$ and $180 \mathrm{mg} / \mathrm{Nm}^{3}$ from corn cob (after the multi-cyclone) and hay briquette combustion. Refs. [64,72] measured mass concentration of particles from combustion of triticale pellets and wood pellets/briquettes to be $183 \mathrm{mg} / \mathrm{Nm}^{3}\left(13\right.$ vol.\% $\left.\mathrm{O}_{2}\right)$ and between 34 and $240 \mathrm{mg} / \mathrm{Nm}^{3}$, more in line with our results. Ref. [73] reported PM-emissions from agropellet combustion in small-scale units to range from 13.8 (for reed canary grass pellets) to $657.7 \mathrm{mg} / \mathrm{Nm}^{3}$ (for sunflower husk pellets). Authors attribute low Si content of sunflower husks as a potential cause of high emissions, due to a lack of silicates to facilitate alkali sorption in the bottom ash. When comparing emissions on an input energy basis, Ref. [23] reported TPM- emissions from maize combustion to be $90 \mathrm{mg} / \mathrm{MJ}$, whereas TPM-emissions from our study are $143 \mathrm{mg} / \mathrm{MJ}$, somewhat higher than the values from aforementioned study, but within a similar order of magnitude. TPM-emissions from the combustion of corn stalk pellets by [65] were $88 \mathrm{~g} / \mathrm{kg}$, whereas those from our experiments were lower, on average $2.2 \mathrm{~g} / \mathrm{kg}$.

Effectiveness of fuel blending for TPM-emission reduction matches previous findings. Ref. [46] investigated the fuel blends of pinewood, Miscanthus, and straw and concluded that increasing straw share in the blends coincides with an increase in total particulate matter (PM) emissions (but not with CO emission increase). The optimal blend share was found to be $70 \mathrm{wt}$. \% wood with $30 \mathrm{wt}$. \% Miscanthus. They also found that a blend of 50 wt. \% wood with 50 wt. \% Miscanthus meet the requirements (emission limit values) of the EN 303-5 standard in real-life conditions. 
TPM-emission reduction of approximately 40 to $50 \%$ is supported by previous studies on crop residue combustion with kaolin $[30,33,42,45,62,74]$. Previous studies support the reduction of particulate matter emission through the use of kaolin as an additive $[30,47,65,75]$. For example, Ref. [42] investigated the addition of kaolin to herbaceous biomass pellets and discovered that $4 \mathrm{wt}$. \% kaolin does indeed significantly reduce $\mathrm{PM}_{1}$ emissions $(p<0.01)$ in Miscanthus and tall fescue pellets (with Miscanthus over $50 \%$ and with tall fescue pellets over $40 \%$ from $300 \mathrm{mg} / \mathrm{m}^{3}$ to $200 \mathrm{mg} / \mathrm{m}^{3}$ ). Ref. [73] reported the reduction of $\mathrm{PM}_{1}$ emissions during oat combustion with kaolin addition: from $0.49 \mathrm{~g} / \mathrm{kg}$ to $0.29 \mathrm{~g} / \mathrm{kg}$, in line with our findings. Our total PM emissions using isokinetic sampling and a filter unit amounted to ca. $2.2 \mathrm{~g} / \mathrm{kg}$ from corn cob pellet combustion and with $1 \mathrm{wt}$. \% kaolin it was reduced to $1.6 \mathrm{~g} / \mathrm{kg}$.

\subsection{Composition of Solid Combustion Products}

Distribution of major ash- and particulate matter forming elements can give insight into reactions taking place in the ash during combustion, enabling the evaluation of the effectiveness of applied measures. In the following section, chemical composition of solid combustion residues will be presented and discussed, with the focus on alkali behaviour during combustion.

\subsubsection{Grate Ash}

Results. Concentrations of $\mathrm{K}, \mathrm{Al}$, and volatiles in g per $\mathrm{kg}$ of fuel $\left(\mathrm{g} / \mathrm{kg}_{\mathrm{FUEL}}\right)$ determined by wet chemical analysis (AAS and IC) are presented in Figure 6, whereas crystalline phases identified by XRD are found in Table 4 Concentration of $\mathrm{K}(\mathrm{g} / \mathrm{kg}$ FUEL $)$ in the GA rises with increasing share of corn cob pellets in the fuel blend, as well as with kaolin addition (indicating K sorption in the grate ash). Products of incomplete combustion are detected in all GA samples, slightly increasing with increasing share of corn cob pellets and further decreasing with the increasing share of kaolin. Most common crystalline phases in fuel blends where wood pellets are dominant were $\mathrm{SiO}_{2}, \mathrm{CaCO}_{3}$, and $\mathrm{CaMn}_{14} \mathrm{SiO}_{24}$, whereas $\mathrm{KCl}$ and $\mathrm{K}_{2} \mathrm{CO}_{3}$ replaced silicates in fuel blends.

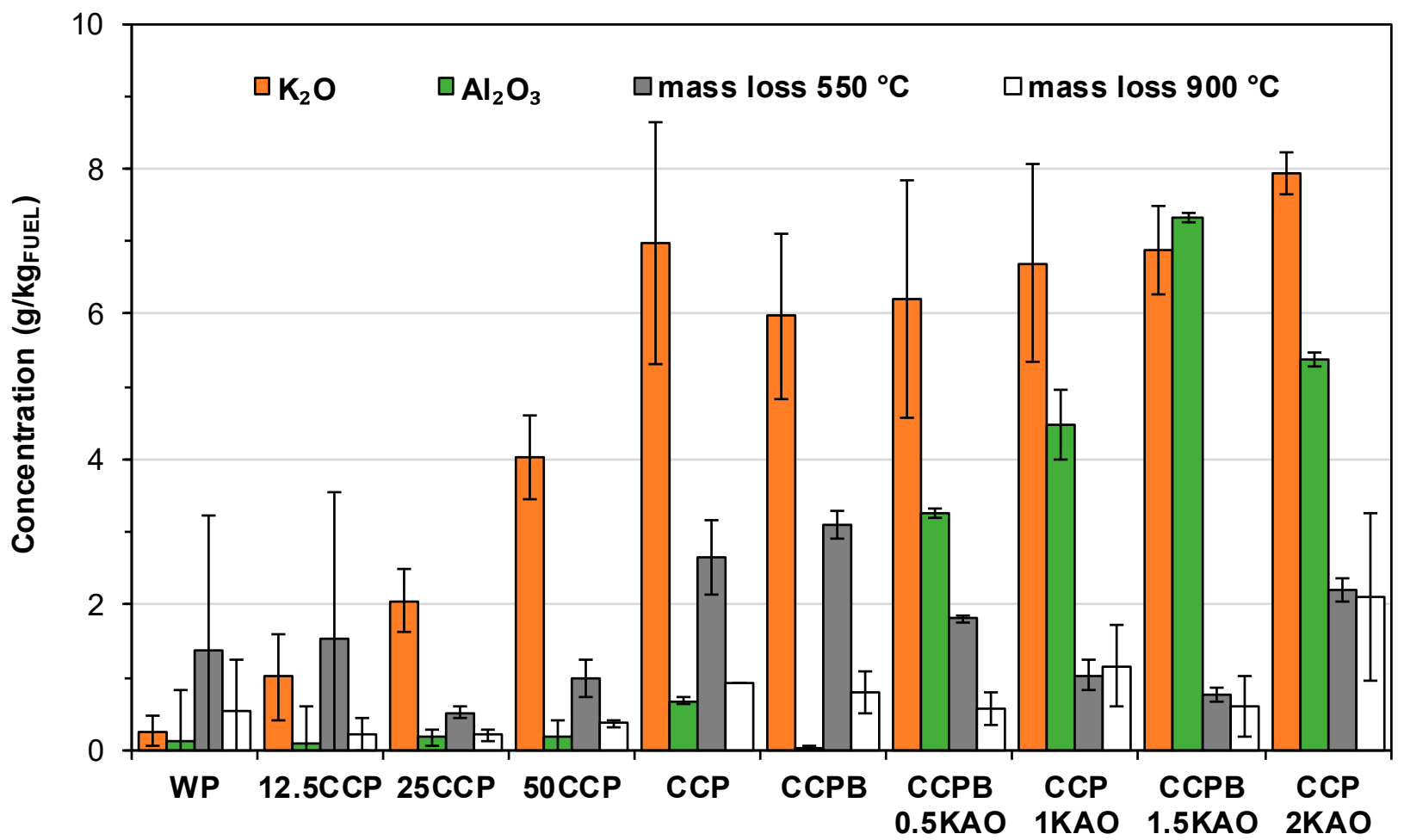

Figure 6. Concentration of selected species in grate ash (for experimental list see Table 2). 
Table 4. Crystalline phases identified in the grate ash (GA) samples (for experimental list see Table 2).

\begin{tabular}{|c|c|c|c|c|c|c|c|c|c|c|c|}
\hline $\begin{array}{l}\text { Crystalline } \\
\text { Phase }\end{array}$ & WP & $12.5 \mathrm{CCP}$ & $25 \mathrm{CCP}$ & $50 \mathrm{CCP}$ & ССР & ССРВ & ССРВ0.5КАО & ССР1КАО & ССРВ1.5КАО & ССР2КАО & Literature \\
\hline $\mathrm{SiO}_{2}$ & $\mathrm{x}$ & $\mathrm{x}$ & $\mathrm{x}$ & & & & & & & & {$[43,76-81]$} \\
\hline $\mathrm{CaCO}_{3}$ & $\mathrm{x}$ & & $\mathrm{x}$ & & $\mathrm{x}$ & & & & & & {$[30,47,78,82-86]$} \\
\hline $\mathrm{KCl}$ & & & & $x$ & $\mathrm{x}$ & & $\mathrm{x}$ & & & & {$[30,79,81,85,87-89]$} \\
\hline $\begin{array}{c}\mathrm{MgU} \\
\mathrm{K}_{2} \mathrm{CO}_{3}\end{array}$ & & & & $x$ & $\mathrm{x}$ & $\mathrm{x}$ & & & & $\mathrm{x}$ & {$[30,43,47,81,83]$} \\
\hline $\begin{array}{c}\mathrm{CaMn}_{14} \mathrm{SiO}_{24} \\
\mathrm{KAlSiO}_{4}\end{array}$ & & $\mathrm{x}$ & $\mathrm{x}$ & $\mathrm{x}$ & & & & $\mathrm{x}$ & $\mathrm{x}$ & $\mathrm{x}$ & $\begin{array}{c}{[90]} \\
{[63,78,79,85]}\end{array}$ \\
\hline
\end{tabular}

Discussion. Increasing concentrations of $\mathrm{K}$ and unburned material with increasing shares of corn cobs in the fuel blend can be traced back to higher contents of alkali in corn cob and to the fact that pellet oven was designed and optimized for DINPlus-certified wood pellet combustion. These findings are supported by the increase in CO-emissions with increasing share of corn cob pellets in the fuel blends (incomplete combustion). Low concentrations of volatiles in grate ash samples with kaolin are in line with CO- and TPMemission reduction after additivation. Increased contents of $\mathrm{Al}$ with increasing kaolin content (Figure 3) illustrate the dilution of the grate ash with additive, which should also be taken into consideration when assessing $\mathrm{K}$ enrichment and sorption in the GA.

Sorption of $\mathrm{K}$ in the grate ash with kaolin is supported by XRD findings (Table 4). In the sample with $1.5 \mathrm{wt}$ \% kaolin (CCPB1.5KAO) high-temperature stabile crystalline $\mathrm{K}$-Al-silicates, which are the products of kaolin decomposition into meta-kaolinite and subsequent reactions with K-species, were identified, but not in the sample with $0.5 \mathrm{wt}$. \% kaolin (CСPB0.5KAO), indicating that $0.5 \mathrm{wt}$. \% kaolin in the fuel is not enough to bind $\mathrm{K}$ in the ash. Active mechanisms for the reduction of TPM-emissions with kaolin are chemical reactions between alkali-compounds such as $\mathrm{KOH}, \mathrm{KCl}$, and $\mathrm{K}_{2} \mathrm{SO}_{4}$, and meta-kaolinite, incorporating $\mathrm{K}$ into temperature-stabile silicates such as $\mathrm{KAlSiO}_{4}$ in the ash. Adsorption of alkalis on meta-kaolinite is also dependent on intraparticle diffusion, which is enhanced due to porous nature of additive after calcination [66-68]. The enrichment of $\mathrm{K}$ in grate ash samples with $1.5 \mathrm{wt}$. \% kaolin is supported by low TPM-emissions from this experiment. However, despite the $\mathrm{K}$ enrichment in the grate ash with 2 wt. \% kaolin respective TPMemissions were increased due to ash entrainment.

Other main ash-forming elements $\mathrm{Ca}, \mathrm{O}$ and $\mathrm{Si}$ are possibly present in the form of $\mathrm{CaO}, \mathrm{SiO}_{2}$, and $\mathrm{CaCO}_{3}$ in the GA samples where wood pellets are dominant, supported by $\mathrm{XRD}$ findings. Carbon is possibly present in the form of alkali- and earth alkali-carbonates, whereas the rest could consist of $\mathrm{K}_{2} \mathrm{O}$ and $\mathrm{CaO}$; supported by results from $\mathrm{XRD}$, where $\mathrm{SiO}_{2}, \mathrm{CaCO}_{3}$ and $\mathrm{MgO}$ were detected. Crystalline $\mathrm{CaCO}_{3}, \mathrm{KCl}$, and $\mathrm{K}_{2} \mathrm{CO}_{3}$ found across grate ash samples indicate lower temperatures in the combustion chamber, since their melting points are $825^{\circ} \mathrm{C}, 760{ }^{\circ} \mathrm{C}$, and $891{ }^{\circ} \mathrm{C}$ [76-78], and are expected to be released during combustion in the form of $\mathrm{CO}_{2}$, and $\mathrm{KCl}_{(\mathrm{g})}$, leaving $\mathrm{CaO}$ in $\mathrm{GA}$.

Results are in line with previous findings [30,41,79-81] regarding the presence of products of incomplete combustion in the grate ash [62] as well as regarding K-Al-silicates in the grate ash with kaolin $[28,74]$ and $\mathrm{K}_{2} \mathrm{O}$ in the grate ash. The presence of silica, calcite, and $\mathrm{CaO}$ is in accordance with the results from the combustion of wood [79-81]. Alumina and magnesia are expected crystalline phases in ash samples from the combustion of wood pellets; this is also in accordance with previous literature results [30,40]. 


\subsubsection{Particulate Matter}

Results. Concentrations of $\mathrm{K}_{2} \mathrm{O}, \mathrm{Cl}^{-}$, and $\mathrm{SO}_{4}{ }^{2-}$ in $\mathrm{mg} / \mathrm{m}^{3}$ of dry flue gas at 10 vol. $\% \mathrm{O}_{2}$, determined by wet chemical analysis (AAS and IC) are found in Figure 7. All three aforementioned particulate matter-forming species are enriched in the TPM with increasing corn cob content, whereas this trend is reversed with the application of kaolin as additive (with the exception of $2 \mathrm{wt}$ \% kaolin).

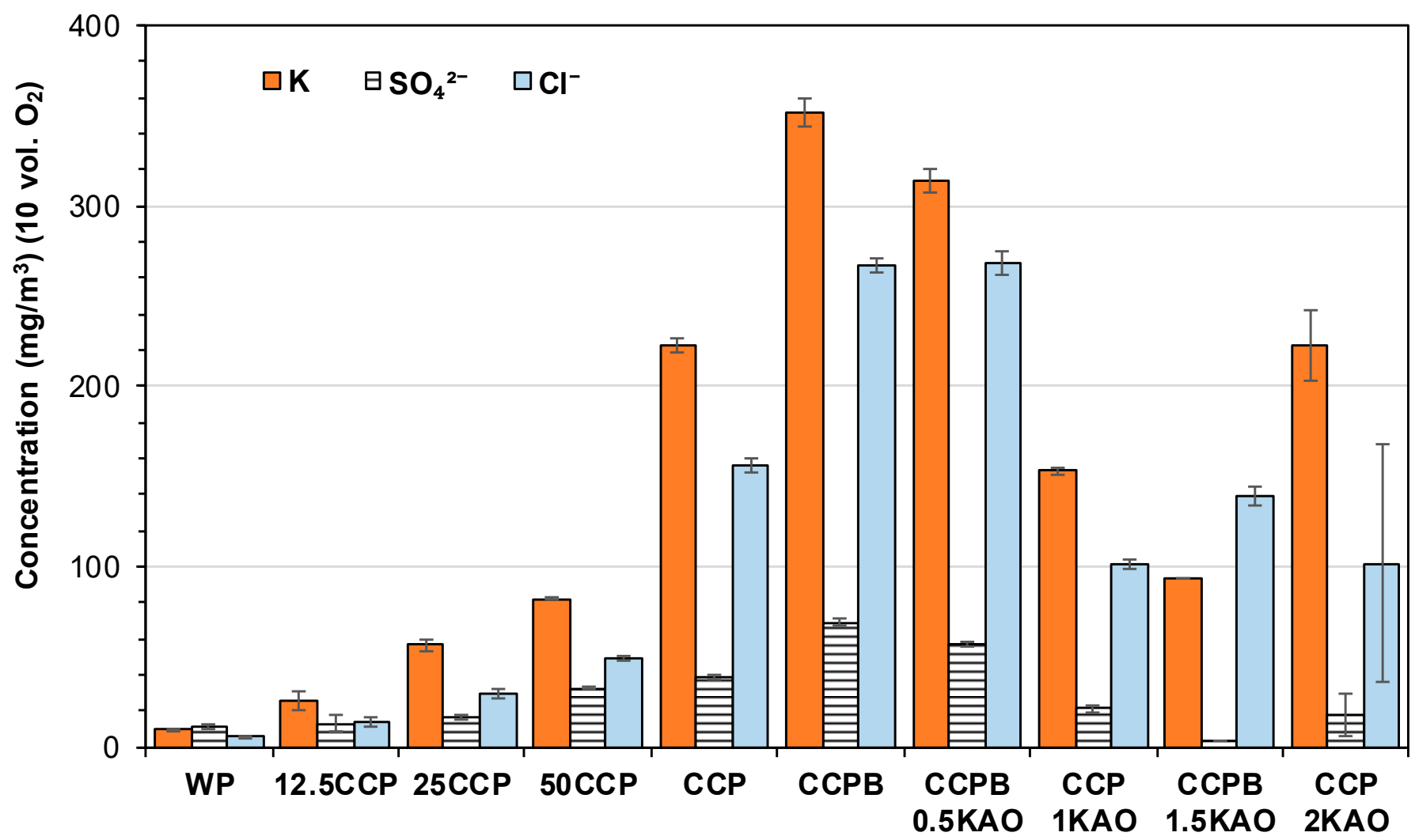

Figure 7. Concentrations of main components in TPM (for experimental list see Table 2).

Micromorphological scans of selected TMP samples determined by scanning electron microscopy (SEM) are found in Figure 8. TPM sample from WP combustion (Figure 8a) is characterized by a uniform structure of ultrafine particles $(<100 \mathrm{~nm})$, agglomerating to form clusters of several $\mu \mathrm{m}$. However, two distinct structures can be observed in SEM images of TPM samples from the combustion of other fuels (Figure 8b-e): (1) primary network made of larger polyhedral and spherical particles approximately $1 \mu \mathrm{m}$ in size, on top of which (2) smaller secondary network of square-prism-shaped particles of approximately $200 \mathrm{~nm}$ in size. In the case of additivized corn cob pellets, focused spot scans again identified "primary network" structures as $\mathrm{KCl}$, on top of which two distinct groups of agglomerations or "secondary network" seem to be formed: (1) one bigger group formed of $\mathrm{KCl}$ and $\mathrm{K}$-Al-silicates (e.g., $4{ }^{* *}$ in the Table 5 CCP1KAO TPM), (2) smaller groups formed from $\mathrm{K}_{2} \mathrm{SO}_{4}$. Molar $\mathrm{K} /(\mathrm{Cl}+2 \mathrm{~S}+\mathrm{Al})$ ratios of surface and spot scans indicate that main PM-forming compounds are $\mathrm{KCl}$ and $\mathrm{K}_{2} \mathrm{SO}_{4}, \mathrm{KCl}$ being dominant in TPM samples from CCP combustion, whereas $\mathrm{K}_{2} \mathrm{SO}_{4}$ is the main compound present in TPM from WP combustion. According to surface and spot scans by Energy Dispersive X-ray Spectroscopy (EDS), all samples contain C, besides $\mathrm{K}, \mathrm{S}, \mathrm{O}$, and $\mathrm{Cl}$ (Table 5). For images of PM samples with regions scanned by EDS, see Appendix A. 


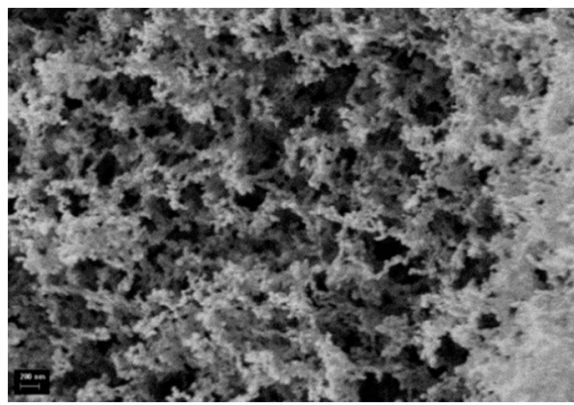

(a)

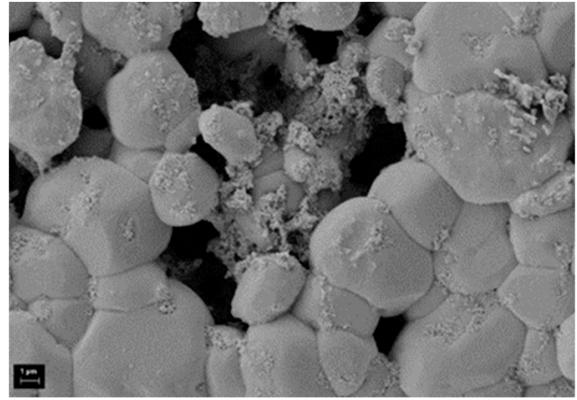

(d)

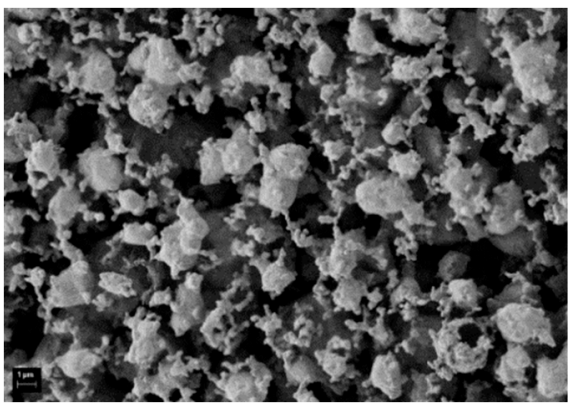

(b)

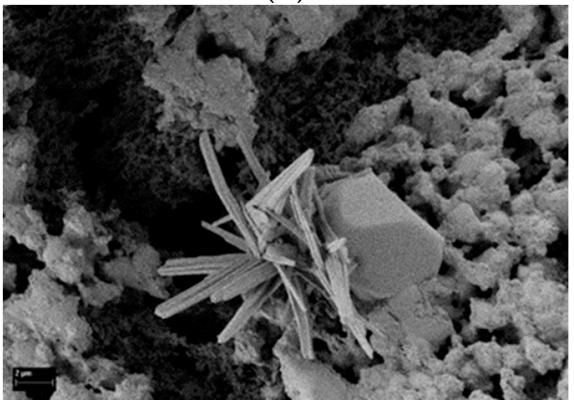

(e)

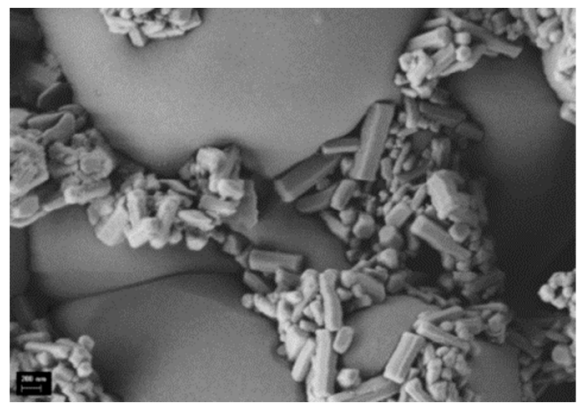

(c)

Figure 8. SEM images of TPM samples (a) WP; (b) 50CCP; (c) CCP; (d) CCP1KAO; (e) CCP2KAO.

Table 5. Composition of TMP samples as determined by EDS (for fuel names see Table 2).

\begin{tabular}{|c|c|c|c|c|c|c|c|c|c|c|c|c|c|c|c|c|c|c|}
\hline \multirow[t]{2}{*}{ (norm, wt. \%) } & \multicolumn{2}{|c|}{ WP TPM } & \multicolumn{3}{|c|}{50 ССР ТРМ } & \multicolumn{3}{|c|}{ ССР ТРМ } & \multicolumn{5}{|c|}{ ССР1КАО ТРМ } & \multicolumn{5}{|c|}{ ССР2КАО ТРМ } \\
\hline & $1 *$ & $2 * *$ & $1 * *$ & $2 * *$ & $3 *$ & $1 *$ & $2 * *$ & $3 *$ & $1 *$ & $2 *$ & $3 * *$ & $4^{* *}$ & $5 * *$ & $1 *$ & $2 * *$ & $3 * *$ & $4 * *$ & $5 * *$ \\
\hline $\mathrm{K}$ & 19.1 & 22.2 & 57.4 & 36.1 & 43.1 & 35.9 & 36.0 & 35.0 & 38.2 & 39.4 & 54.5 & 35.9 & 59.5 & 26.7 & 24.3 & 45.0 & 46.3 & 40.9 \\
\hline $\mathrm{Na}$ & - & - & - & - & - & - & - & - & - & - & - & - & - & - & 0.2 & - & - & - \\
\hline $\mathrm{Si}$ & 1.1 & - & - & - & - & 0.2 & - & 0.6 & 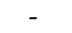 & 0.3 & - & 12.2 & . & 0.3 & 0.3 & - & - & - \\
\hline $\mathrm{Al}$ & - & - & - & - & - & 0.1 & - & 0.1 & 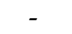 & - & - & 8.3 & - & & & - & - & - \\
\hline $\mathrm{P}$ & - & - & - & - & - & - & - & - & - & - & - & - & - & 1.0 & 0.8 & - & - & - \\
\hline $\mathrm{S}$ & 4.2 & - & - & 13.0 & 6.6 & 3.8 & 3.7 & 3.4 & 1.8 & 1.4 & - & - & - & 1.7 & 1.4 & - & 2.6 & 4.5 \\
\hline $\mathrm{C}$ & 53.6 & 53.5 & - & 15.7 & 14.7 & 18.5 & 16.9 & 19.9 & 20.8 & 18.2 & - & - & - & 39.7 & 44.0 & 16.7 & 11.2 & 15.5 \\
\hline $\mathrm{O}$ & 14.5 & 15.9 & - & 26.8 & 12.3 & 15.5 & 18.0 & 15.5 & 9.0 & 8.5 & - & 36.8 & - & 11.4 & 10.7 & 5.9 & 7.5 & 15.2 \\
\hline $\mathrm{Cl}$ & 7.7 & 8.4 & 42.6 & 8.4 & 23.3 & 26.0 & 25.5 & 25.4 & 30.2 & 32.2 & 45.6 & 6.8 & 40.5 & 19.3 & 18.3 & 32.4 & 32.4 & 23.9 \\
\hline $\mathrm{K} / \mathrm{Cl}^{* * *}$ & 2.3 & 2.4 & 1.2 & 3.9 & 1.7 & 1.3 & 1.3 & 1.3 & 1.2 & 1.1 & 1.1 & 4.8 & 1.3 & 1.3 & 1.2 & 1.3 & 1.3 & 1.6 \\
\hline $\mathrm{K} /(\mathrm{Cl}+2 \mathrm{~S})$ & 1.0 & 2.4 & 1.2 & 0.9 & 1.0 & 0.9 & 1.0 & 1.0 & 1.0 & 1.0 & 1.1 & 4.8 & 1.3 & 1.1 & 1.0 & 1.3 & 1.1 & 1.1 \\
\hline $\mathrm{K} /(\mathrm{Cl}+2 \mathrm{~S}+\mathrm{Al})$ & 1.0 & 2.4 & 1.2 & 0.9 & 1.0 & 0.9 & 1.0 & 1.0 & 1.0 & 1.0 & 1.1 & 1.8 & 1.3 & 1.1 & 1.0 & 1.3 & 1.1 & 1.1 \\
\hline
\end{tabular}

Discussion. The correlations between fuel properties driving the TPM formation and TPM-emission are illustrated in Figure 9. TPM-emissions in $\mathrm{mg} / \mathrm{m}^{3}$ (standard conditions and 10 vol. $\% \mathrm{O}_{2}$ ) are compared with $\mathrm{K}$ recovery in the grate ash (concentration of $\mathrm{K}$ in the grate ash relative to concentration of $\mathrm{K}$ in the biomass) in \%, and molar ratio $\mathrm{K} /(\mathrm{Cl}+2 \mathrm{~S}+\mathrm{Al})$ in the biomass. There are strong correlations between aforementioned molar ratio and TPM-emission as well as between the molar ratio and $\mathrm{K}$ recovery in the ash (Pearson coef. 0.83 and 0.85, respectively). Point (1) in the Figure 9 with the lowest TPM-emission and lowest molar $\mathrm{K} /(\mathrm{Cl}+2 \mathrm{~S}+\mathrm{Al}$ ) ratio represents $\mathrm{WP}$ combustion (low $\mathrm{K}$ content), whereas highest point in this plane (2) is associated with non-additivized CCP combustion (high K content). After kaolin addition Si content of biomass increases enabling even better K sorption in the corn cob GA (3) (lower molar ratio due to increased Si content). On the other hand, $\mathrm{K}$ recovery in the grate ash shows a reverse trend, indicating that $\mathrm{K}$ is massively released into the gaseous phase during wood combustion (due to low Si content in the WP GA), whereas higher percentage of $\mathrm{K}$ is bound in the grate ash during corn cob combustion (due to high Si content). This is why in some studies biogenic silica is added to woody biomass to bind alkali in the GA [2]. However, even though there is increased Si content in corn cob in comparison to wood, it is not enough to bind extremely high $\mathrm{K}$ 
amounts. This is where kaolin takes the role of external reactive Si source and binds alkali in K-Al-silicates. Effect of kaolin addition is evident: both TPM-emission and molar ratio $\mathrm{K} /(\mathrm{Cl}+2 \mathrm{~S}+\mathrm{Al})$ are reduced, but $\mathrm{K}$ sorption (recovery) in the GA is increased.

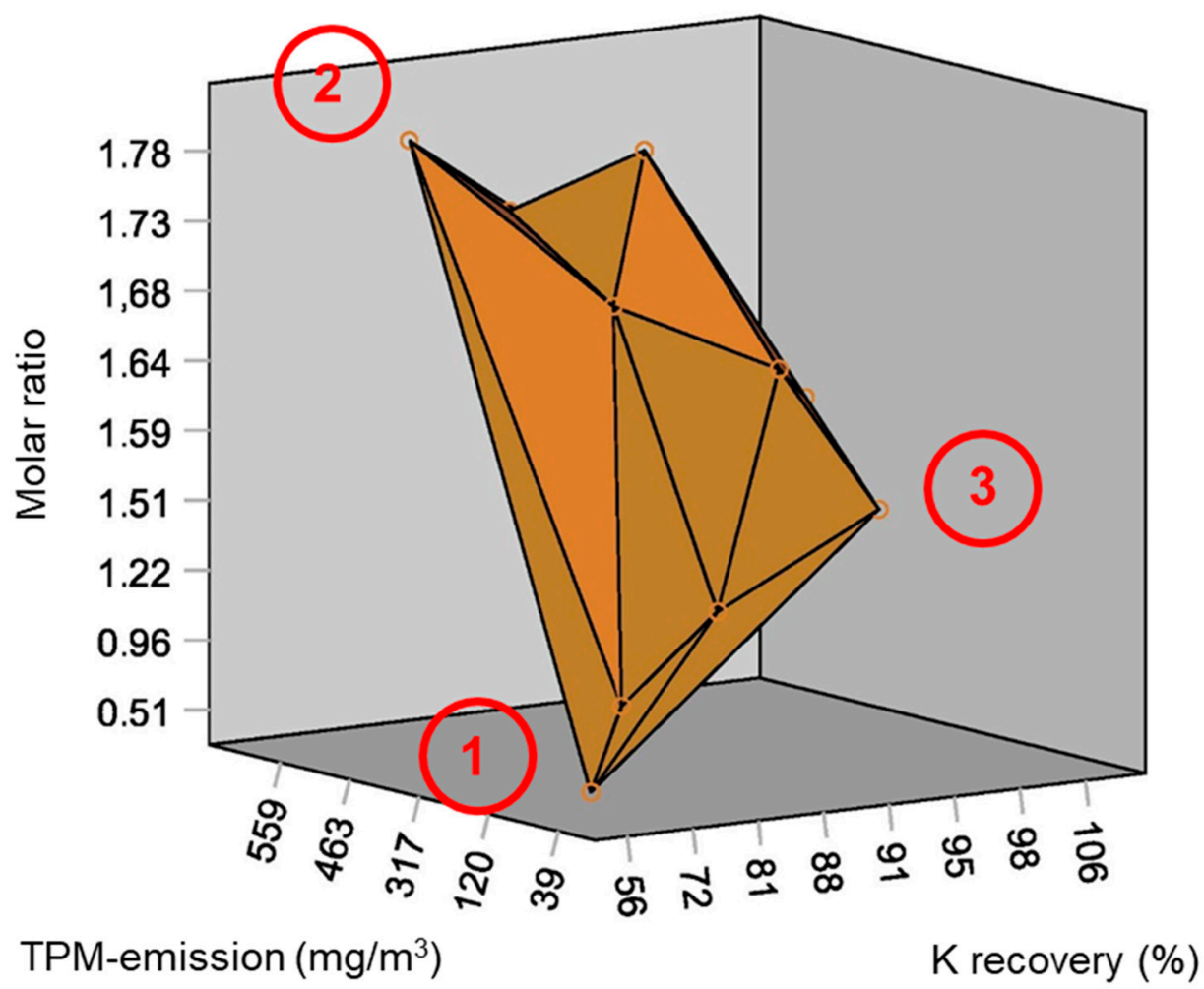

Figure 9. Comparison of TPM-emissions in $\mathrm{mg} / \mathrm{m}^{3}, \mathrm{~K}$ recovery rate in GA in \%, and molar $\mathrm{K} /(\mathrm{Cl}+2 \mathrm{~S}+\mathrm{Al})$ ratio in biomass.

Increased contents of $\mathrm{K}, \mathrm{SO}_{4}{ }^{2-}$, and $\mathrm{Cl}^{-}$in TPM in Figure 7 with increasing share of corn cob material in the fuel blends follow the same trend observed in GA samples (Section 3.4.1) and can be traced back to the (1) content of ash forming matter in the fuel, and (2) $\mathrm{K}$ speciation. Release of $\mathrm{K}, \mathrm{Cl}$, and $\mathrm{S}$ is generally reliant on vaporization-condensation mechanism, which also depends on their speciation in the plant. $\mathrm{K}$ and $\mathrm{Cl}$ are mainly found as free ions in the plant fluids' solution and precipitate as salts during drying. Exact association and distribution of $\mathrm{K}$ and $\mathrm{Cl}$ in the biomass, however, depend on plant species, growth conditions, and handling (weathering, leaching etc.) [82]. If $\mathrm{K}$ is present in inorganic form it is released as $\mathrm{KCl}$ at temperatures $>700{ }^{\circ} \mathrm{C}$, whereas if present in organic form, it is released as gaseous $\mathrm{K}$ or $\mathrm{K}_{2} \mathrm{O}$. These species then react with $\mathrm{HCl}$, water vapor or $\mathrm{CO}_{2}$ to form gaseous $\mathrm{KCl}, \mathrm{KOH}$, and $\mathrm{K}_{2} \mathrm{SO}_{4(\mathrm{~g})}$, which react with each other in the gaseous phase (Equations (2)-(4)) and subsequently go through nucleation (during cooling), followed by coagulation, heterogenic condensation and agglomeration, forming total particulate matter, or are adsorbed on top of existing coarser particulates $[64,83,84]$. $S$ is, on the other hand, partially metabolized and incorporated into the organic matter of the plant. Sulphation could potentially influence the formation of condensation structures even with same amount of $S$ in the biomass [85], e.g., deposits from corn stover combustion (major association of $S$ in organic form) are different than those from wheat straw combustion (higher fraction of $S$ in sulfate form) [85]. During combustion organically bound $S$ is released in the form of $\mathrm{SO}_{2}$ during devolatilization stage and less $\mathrm{S}$ is available to be released later during thermal decomposition of inorganic matter $\left(>700^{\circ} \mathrm{C}\right)$ [86]. Therefore, since $\mathrm{S}$ is mainly bound in organic matrix in corn plant, high-temperature release, sulphation and condensation of S-compounds in the TPM will have a subordinate role to $\mathrm{KCl}$ [85]. 


$$
\begin{gathered}
2 \mathrm{KOH}_{(\mathrm{g})}+\mathrm{SO}_{3(\mathrm{~g})}+\rightarrow \mathrm{K}_{2} \mathrm{SO}_{4(\mathrm{~g})}+\mathrm{H}_{2} \mathrm{O}_{(\mathrm{g})} \\
\mathrm{KOH}_{(\mathrm{g})}+\mathrm{HCl}_{(\mathrm{g})} \rightarrow \mathrm{KCl}_{(\mathrm{g})}+\mathrm{H}_{2} \mathrm{O}_{(\mathrm{g})} \\
2 \mathrm{KCl}_{(\mathrm{g})}+\mathrm{SO}_{2(\mathrm{~g})}+\mathrm{H}_{2} \mathrm{O}_{(\mathrm{g})}+\frac{1}{2} \mathrm{O}_{2(\mathrm{~g})} \rightarrow \mathrm{K}_{2} \mathrm{SO}_{4(\mathrm{~g})}+2 \mathrm{HCl}_{(\mathrm{g})} \\
2 \mathrm{KOH}_{(\mathrm{g})}+\mathrm{SiO}_{2} \rightarrow \mathrm{K}_{2} \mathrm{O} \cdot \mathrm{SiO}_{2}+\mathrm{H}_{2} \mathrm{O}_{(\mathrm{g})} \\
2 \mathrm{KOH}_{(\mathrm{g})}+\mathrm{Al}_{2} \mathrm{Si}_{2} \mathrm{O}_{7} \rightarrow 2 \mathrm{KAlSiO}_{4}+\mathrm{H}_{2} \mathrm{O}_{(\mathrm{g})} \\
2 \mathrm{KCl}_{(\mathrm{g})}+\mathrm{Al}_{2} \mathrm{Si}_{2} \mathrm{O}_{7}+\mathrm{H}_{2} \mathrm{O}_{(\mathrm{g})} \rightarrow 2 \mathrm{KAlSiO}_{4}+2 \mathrm{HCl}_{(\mathrm{g})} \\
\mathrm{K}_{2} \mathrm{SO}_{4(\mathrm{~g})}+\mathrm{Al}_{2} \mathrm{Si}_{2} \mathrm{O}_{7} \rightarrow 2 \mathrm{KAlSiO}_{4}+\mathrm{SO}_{3(\mathrm{~g})}
\end{gathered}
$$

Silicates and aluminosilicates in the GA show great affinity towards gaseous $\mathrm{K}$ (Equation (5)). K sorption in silicates occurs during char burnout phase when $\mathrm{Si}$ and $\mathrm{K}$ are in contact after the destruction of the organic matrix [2]. However, the incorporation of $\mathrm{K}$ in silicates is inhibited by the presence of $\mathrm{Ca}$ and similar cations in the cell wall [86] and low content of $\mathrm{Si}$, as is the case with wood pellet combustion. That is why only half of total $\mathrm{K}$ amount is recovered in the grate ash during wood combustion. However, due to overall lower K amount respective TPM-emissions are lower. The presence of $\mathrm{Si}$ in the grate ash of corn cob in this case acts as $\mathrm{K}$ sorbent and prevents full $\mathrm{K}$ release in the flue gas.

On the other hand, decreasing trend of $\mathrm{K}, \mathrm{SO}_{4}{ }^{2-}$, and $\mathrm{Cl}^{-}$concentration $\left(\mathrm{mg} / \mathrm{m}^{3}\right)$ in TPM samples (Figure 7) with increasing kaolin content indicates the reduction of $\mathrm{K}$ release into the gaseous phase. This is achieved through chemical reactions between released volatile species $\mathrm{KOH}_{(\mathrm{g})}, \mathrm{KCl}_{(\mathrm{g})}, \mathrm{K}_{2} \mathrm{SO}_{4(\mathrm{~g})}$ (Equations (2) and (3)) and meta-kaolinite in the grate ash at temperatures $800-1200{ }^{\circ} \mathrm{C}$ (Equations (6)-(8)), forming $\mathrm{KalSiO}_{4}$ (supported by XRD findings and results from Figure 9), whereas $\mathrm{SO}_{4}{ }^{2-}$, and $\mathrm{Cl}^{-}$are released in the gaseous form through reactions described in Equations (7) and (8). Increased values of $\mathrm{K}, \mathrm{SO}_{4}{ }^{2-}$, and $\mathrm{Cl}^{-}$concentrations in the flue gas in the case of $2 \mathrm{wt}$. \% kaolin are due to increased overall TPM-emission with 2 wt. \% kaolin (Table 3), which in turn influences the specific concentrations of elements per $\mathrm{m}^{3}$ of dry flue gas.

Molar ratios from Table 5 indicate that TPM from WP combustion is mostly made of $\mathrm{KCl}$ and $\mathrm{K}_{2} \mathrm{SO}_{4}$ (molar $\mathrm{K} /(\mathrm{Cl}+2 \mathrm{~S})$ ratio approximately 1 on surface scan), but additionally carbonaceous matter (probably soot) and possibly other K-species such as $\mathrm{K}_{2} \mathrm{CO}_{3}$ $(\mathrm{K} /(\mathrm{Cl}+2 \mathrm{~S}+\mathrm{Al})$ ratio 2.4 in spot scan). According to calculations where $\mathrm{KCl}$ is preferably formed, followed by $\mathrm{K}_{2} \mathrm{SO}_{4}$, and $\mathrm{K}_{2} \mathrm{CO}_{3}$, TPM WP sample is composed of approximately 23 wt. $\% \mathrm{~K}_{2} \mathrm{SO}_{4}, 16$ wt. $\% \mathrm{KCl}, 4$ wt. $\% \mathrm{~K}_{2} \mathrm{CO}_{3}$, and 6 wt. $\% \mathrm{~K}_{2} \mathrm{SiO}_{3}$, indicating that $\mathrm{K}_{2} \mathrm{SO}_{4}$ is the main component of TPM from wood pellet combustion. In fuel blends, $\mathrm{KCl}$ takes on the dominant role: approximately $49 \mathrm{wt} . \%$ and $54 \mathrm{wt}$ \% of the 50CCP and CCP TPM samples is composed of $\mathrm{KCl}$, followed with $34 \mathrm{wt} . \%$ and $17 \mathrm{wt}$. \% by $\mathrm{K}_{2} \mathrm{SO}_{4}$, and C with 14 wt. \% and 18 wt. \%, respectively. Based on EDS scanning (Table 5), aforementioned "primary network" is made of $\mathrm{KCl}$, and the "secondary network" of $>50$ wt. $\% \mathrm{~K}_{2} \mathrm{SO}_{4}$, $18 \mathrm{wt} . \% \mathrm{KCl}, 9$ wt. \% soot, and $4 \mathrm{wt}$. $\% \mathrm{~K}_{2} \mathrm{CO}_{3}$. Therefore, $\mathrm{KCl}$ is the main condensing $\mathrm{K}$-salt from the combustion of corn cob pellets, whereas $\mathrm{K}_{2} \mathrm{SO}_{4}$ seems to be more important in the combustion of wood pellets. Similar results are observed for surface scans of additivized TPM samples, with and exception regarding targeted spot scans with molar ratio of $\mathrm{K} /(\mathrm{Cl}+2 \mathrm{~S}+\mathrm{Al})$ of 1.8 , which reveal the presence of other $\mathrm{K}$-species, more specifically $\mathrm{K}$-Al-silicates. The presence of $\mathrm{Al}$ and $\mathrm{Si}$ in the spot scan of total particulate matter from samples with kaolin is most likely caused by fragmentation of K-Al-silicates, entrainment into the flue gas, and coalescence.

The dominant role of $\mathrm{KCl}$, the presence of $\mathrm{KCl}$ primary network, and our findings regarding composition, association of elements, and microstructure of TPM are supported by results from previous studies $[6,72,86,88,89]$, which report presence of clinker-shaped particles and cluster agglomerations dominated by $\mathrm{KCl}$ in $\mathrm{PM}_{1}$ from corn stover combustion $\left(\mathrm{KCl}, \mathrm{K}_{2} \mathrm{CO}_{3}\right.$, and $\mathrm{KOH}$ which form through solid-gaseous-particle pathway), whereas 
$\mathrm{PM}_{2.5}$ is composed of $\mathrm{Si}, \mathrm{K}, \mathrm{Ca}$, and $\mathrm{Mg}$. Our findings are also in accordance with those from [89], who reported that fine particles from wood combustion mainly consist of agglomerates of few primary particles characterized by a compact structure. The presence of $\mathrm{K}_{2} \mathrm{SO}_{4}$ and carbonaceous soot as main total particulate matter components from residential wood combustion (soot release due to low temperatures in combustion chamber) are in accordance with findings from $[30,59,63,88,89]$. The presence of carbonaceous matter in $\mathrm{PM}$ is in accordance with previous studies regarding wood pellet combustion [30,63,89]. Soot was reported to be one of the main components of particulate matter from residential wood combustion (due to incomplete combustion with low temperatures in small scale units) $[59,88]$. Studies by $[89,90]$ reported that alkali and earth alkali silicates are responsible for the formation of coarser TPM particles, further exacerbated via the entrainment of kaolin from grate ash, supporting our findings. Reduction of K concentration in the TPM with kaolin with contrasting information regarding $\mathrm{SO}_{4}{ }^{2-}$, and $\mathrm{Cl}^{-}$behavior is supported by previous studies $[25,26,30,42,91]$.

\section{Conclusions}

In order to improve corn cob fuel properties, making it more appropriate for use in small-scale heating units in rural areas, fuel-related measures such as additivation of corn cob pellets with kaolin and fuel blending with wood pellets have been investigated in this study. With the aim of mitigating total particulate matter (TPM) emissions, additivized and non-additivized corn cob pellets, as well as fuel blends consisting of wood and corn cob pellets, were combusted in a $8 \mathrm{~kW}$ state-of-the-art pellet oven under full load.

Fuel-related measures were successful in reducing TPM-emissions (in comparison with non-additivized corn cob pellet combustion as reference), as follows:

- Blending $50 \mathrm{wt}$. \% corn cob pellets with $50 \mathrm{wt}$. \% wood pellets resulted in $60 \mathrm{wt}$. \% and 64 wt. \% reduction in TPM-emissions and CO-emissions, respectively. Fuel blending influences TPM-emissions by reducing total $\mathrm{K}$ content of the fuel.

- Using $1.5 \mathrm{wt}$. \% kaolin as additive, resulted in approximately $48 \mathrm{wt}$. \% and $89 \mathrm{wt}$. \% reduction in TPM- and CO-emissions respectively, as observed. Kaolin binds volatile alkali metals in high-temperature stabile K-Al-silicates in the grate ash, thereby minimizing TPM-emission and preventing ash sintering. However, entrainment of ash into the combustion chamber was considerable due to increased ash content.

TPM from corn cob combustion consists primarily of $\mathrm{KCl}$, whereas $\mathrm{K}_{2} \mathrm{SO}_{4}$ is the dominant compound in the TPM from wood pellet combustion. Decreasing trend of $\mathrm{K}, \mathrm{SO}_{4}{ }^{2-}$, and $\mathrm{Cl}^{-}$concentration in the TPM has been observed with kaolin addition. Morphologically TPM consists of a "primary network" - polyhedral and spherical particles approximately $1 \mu \mathrm{m}$ in size and mainly composed of $\mathrm{KCl}$, and a "secondary network" built on top of the primary network, consisting of square-prism-shaped particles of approximately $200 \mathrm{~nm}$ in size.

Overall, it has been shown that low-cost fuel-engineering measures are effective in reducing TPM- and CO-emissions and preventing ash sintering during combustion of crop residues in small-scale combustion units. This in turn can not only contribute e to increased air-quality and minimize associated health risks, but also facilitate renewable heat provision and energy independence of rural regions. Based on the results of this study, fuel-upgrading procedures can be further developed with the aim of enabling more environmentally friendly thermochemical biomass utilization in small and medium scale them in rural regions.

Further research is necessary to find the optimal amount of kaolin, which requires adjustment of state-of-the-art method (stoichiometrically calculated amount of kaolin) in pilot- and real-scale applications to take additional parameters such as combustion chamber size and possible entrainment of grate ash into the flue gas into consideration. In addition, the effect of kaolin on CO-emissions reduction and particle size distribution of emitted particulate matter should be investigated in more detail. Moreover, even though significant TPM-emissions has been achieved by applying primary measures, additional low-cost 
relatively simple secondary flue gas treatment appliances, such as cyclones, should be investigated in order to meet emission limit values stipulated by the ever-stricter legislative.

Author Contributions: Conceptualization, N.D.; methodology, N.D., I.H. and M.K.; software, N.D.; validation, N.D., I.H. and M.K.; formal analysis, N.D.; investigation, N.D.; resources, N.D.; data curation, N.D.; writing—original draft preparation, N.D.; writing-review and editing, I.H. and M.K.; visualization, N.D.; supervision, I.H. and M.K.; project administration, N.D.; funding acquisition, M.K. and N.D. All authors have read and agreed to the published version of the manuscript.

Funding: This research was funded by Deutsche Bundesstiftung Umwelt (DBU), grant number 33897/01 und 33897/02, and Scholarship of the Hanseatic City of Hamburg. Publishing of this paper supported by Funding Programme "Open Access Publishing" of Hamburg University of Technology (TUHH).

Conflicts of Interest: The authors declare no conflict of interest.

\section{Appendix A}

SEM images of surface and spot scans by EDS are found in Figure A1.

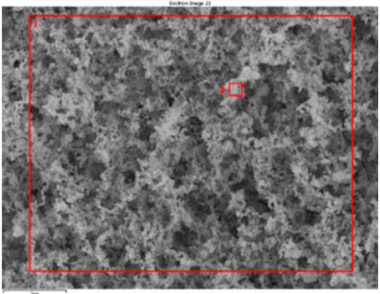

(a)

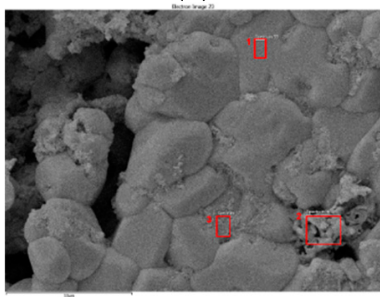

(e)

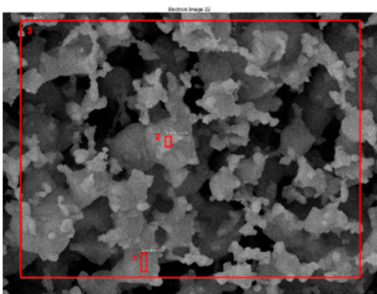

(b)

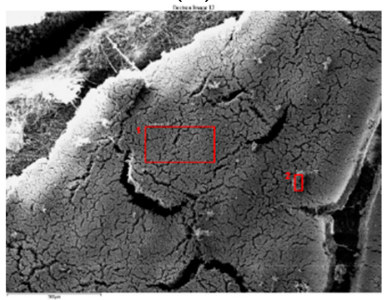

(f)

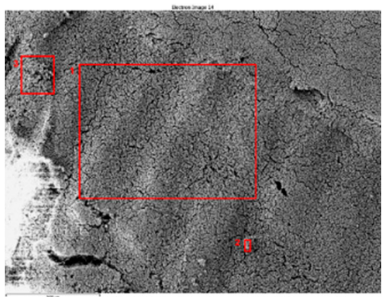

(c)

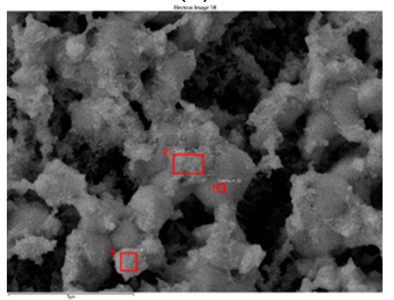

(g)

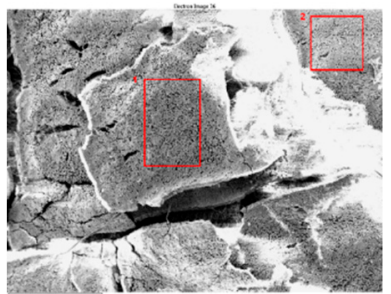

(d)

Figure A1. TPM samples with scanned regions (a) WP; (b) 50CCP; (c) CCP; (d) CCP1KAO (1); (e) CCP1KAO (2); (f) CCP2KAO (1); (g) CCP2KAO (2).

\section{References}

1. International Renewable Energy Agency (IRENA). World Energy Transitions Outlook: $1.5^{\circ} \mathrm{C}$ Pathway. Abu Dhabi, 2021. Available online: https://www.irena.org/publications/2021/Jun/World-Energy-Transitions-Outlook (accessed on 24 July 2021).

2. Rebbling, A.; Sundberg, P.; Fagerström, J.; Carlborg, M.; Tullin, C.; Boström, D.; Öhman, M.; Boman, C.; Skoglund, N. Demonstrating Fuel Design To Reduce Particulate Emissions and Control Slagging in Industrial-Scale Grate Combustion of Woody Biomass. Energy Fuels 2020, 34, 2574-2583. [CrossRef]

3. FAOSTAT. FAOSTAT Crop Statistics. Available online: http://www.fao.org/faostat/en/\#data/QC (accessed on 16 November 2020).

4. Kaltschmitt, M.; Hartmann, H.; Hofbauer, H. Energie aus Biomasse; Springer: Berlin/Heidelberg, Germany, 2016; ISBN 978-3-66247437-2.

5. Wang, C.; Wu, Y.; Liu, Q.; Yang, H.; Wang, F. Analysis of the behaviour of pollutant gas emissions during wheat straw/coal cofiring by TG-FTIR. Fuel Process. Technol. 2011, 92, 1037-1041. [CrossRef]

6. Brunner, T.; Kanzian, W.; Obernberger, I.; Theissl, A. Combustion properties of maize cobs-results from lab and pilot scale tests. In Proceedings of the 19th European Biomass Conference and Exhibition, Berlin, Germany, 6-9 June 2011.

7. Sommersacher, P.; Brunner, T.; Obernberger, I. Fuel Indexes: A Novel Method for the Evaluation of Relevant Combustion Properties of New Biomass Fuels. Energy Fuels 2012, 26, 380-390. [CrossRef]

8. Zeng, T.; Kuptz, D.; Schreiber, K.; Schön, C.; Schulmeyer, F.; Zelinski, V.; Pollex, A.; Borchert, H.; Loewen, A.; Hartmann, H.; et al. Impact of adhering soil and other extraneous impurities on the combustion and emission behavior of forest residue wood chips in an automatically stoked small-scale boiler. Biomass Conv. Bioref. 2019, 9, 99-116. [CrossRef] 
9. Xiong, S.; Burvall, J.; Örberg, H.; Kalen, G.; Thyrel, M.; Öhman, M.; Boström, D. Slagging Characteristics during Combustion of Corn Stovers with and without Kaolin and Calcite. Energy Fuels 2008, 22, 3465-3470. [CrossRef]

10. Aho, M.; Paakkinen, K.; Taipale, R. Quality of deposits during grate combustion of corn stover and wood chip blends. Fuel 2013, 104, 476-487. [CrossRef]

11. Niu, Y.; Tan, H.; Hui, S. Ash-related issues during biomass combustion: Alkali-induced slagging, silicate melt-induced slagging (ash fusion), agglomeration, corrosion, ash utilization, and related countermeasures. Prog. Energy Combust. Sci. 2016, 52, 1-61. [CrossRef]

12. Szymajda, A.; Łaska, G.; Joka, M. Assessment of Cow Dung Pellets as a Renewable Solid Fuel in Direct Combustion Technologies. Energies 2021, 14, 1192. [CrossRef]

13. Comm/dg/unit. EU Climate Action and the European Green Deal—Climate Action-European Commission. Available online: https:/ / ec.europa.eu/clima/policies/eu-climate-action_en (accessed on 14 July 2021).

14. Aman, M. Measures to Address Air Pollution from Small Combustion Sources; International Institute for Applied Systems Analysis \& Umweltbundesamt: Laxenburg, Austria, 2018.

15. Rebbling, A. Dissertation: Application of Fuel Design to Mitigate Ash-Related Problems During Combustion of Biomass; Umea University: Umea, Sweden, 2019.

16. Skoglund, N.; Werner, K.; Nylund, G.M.; Pavia, H.; Albers, E.; Broström, M. Combustion of seaweed-A fuel design strategy. Fuel Process. Technol. 2017, 165, 155-161. [CrossRef]

17. Skoglund, N.; Bäfver, L.; Fahlström, J.; Holmén, E.; Renström, C. Fuel design in co-combustion of demolition wood chips and municipal sewage sludge. Fuel Process. Technol. 2016, 141, 196-201. [CrossRef]

18. Djatkov, D.; Martinov, M.; Kaltschmitt, M. Influencing parameters on mechanical-physical properties of pellet fuel made from corn harvest residues. Biomass Bioenergy 2018, 119, 418-428. [CrossRef]

19. Miranda, M.T.; Sepúlveda, F.J.; Arranz, J.I.; Montero, I.; Rojas, C.V. Analysis of pelletizing from corn cob waste. J. Environ. Manag. 2018, 228, 303-311. [CrossRef]

20. Labbé, R.; Paczkowski, S.; Knappe, V.; Russ, M.; Wöhler, M.; Pelz, S. Effect of feedstock particle size distribution and feedstock moisture content on pellet production efficiency, pellet quality, transport and combustion emissions. Fuel 2020, $263,116662$. [CrossRef]

21. Wei, W.; Zhang, W.; Hu, D.; Ou, L.; Tong, Y.; Shen, G.; Shen, H.; Wang, X. Emissions of carbon monoxide and carbon dioxide from uncompressed and pelletized biomass fuel burning in typical household stoves in China. Atmos. Environ. 2012, 56, 136-142. [CrossRef]

22. Yang, W.; Zhu, Y.; Cheng, W.; Sang, H.; Xu, H.; Yang, H.; Chen, H. Effect of minerals and binders on particulate matter emission from biomass pellets combustion. Appl. Energy 2018, 215, 106-115. [CrossRef]

23. Carvalho, L.; Wopienka, E.; Pointner, C.; Lundgren, J.; Verma, V.K.; Haslinger, W.; Schmidl, C. Performance of a pellet boiler fired with agricultural fuels. Appl. Energy 2013, 104, 286-296. [CrossRef]

24. Zeng, T.; Pollex, A.; Weller, N.; Lenz, V.; Nelles, M. Blended biomass pellets as fuel for small scale combustion appliances: Effect of blending on slag formation in the bottom ash and pre-evaluation options. Fuel 2018, 212, 108-116. [CrossRef]

25. Bäfver, L.; Rönnback, M.; Leckner, B.; Claesson, F.; Tullin, C. Particle emission from combustion of oat grain and its potential reduction by addition of limestone or kaolin. Fuel Process. Technol. 2009, 90, 353-359. [CrossRef]

26. Boström, D.; Grimm, A.; Boman, C.; Björnbom, E.; Öhman, M. Influence of Kaolin and Calcite Additives on Ash Transformations in Small-Scale Combustion of Oat. Energy Fuels 2009, 23, 5184-5190. [CrossRef]

27. Wang, L.; Hustad, J.E.; Skreiberg, Ø.; Skjevrak, G.; Grønli, M. A Critical Review on Additives to Reduce Ash Related Operation Problems in Biomass Combustion Applications. Energy Procedia 2012, 20, 20-29. [CrossRef]

28. Dragutinovic, N.; Höfer, I.; Kaltschmitt, M. Effect of additives on thermochemical conversion of solid biofuel blends from wheat straw, corn stover, and corn cob. Biomass Conv. Bioref. 2019, 9, 35-54. [CrossRef]

29. Höfer, I.; Kaltschmitt, M. Assessment of additives avoiding the release of problematic species into the gas phase during biomass combustion-Development of a fast screening method based on TGA. Biomass Conv. Bioref. 2019, 9, 21-33. [CrossRef]

30. Huelsmann, T.; Mack, R.; Kaltschmitt, M.; Hartmann, H. Influence of kaolinite on the PM emissions from small-scale combustion. Biomass Conv. Bioref. 2019, 9, 55-70. [CrossRef]

31. Khalil, R.A.; Todorovic, D.; Skreiberg, O.; Becidan, M.; Backman, R.; Goile, F.; Skreiberg, A.; Sørum, L. The effect of kaolin on the combustion of demolition wood under well-controlled conditions. Waste Manag. Res. 2012, 30, 672-680. [CrossRef] [PubMed]

32. Konsomboon, S.; Pipatmanomai, S.; Madhiyanon, T.; Tia, S. Effect of kaolin addition on ash characteristics of palm empty fruit bunch (EFB) upon combustion. Appl. Energy 2011, 88, 298-305. [CrossRef]

33. Gollmer, C.; Höfer, I.; Kaltschmitt, M. Additives as a fuel-oriented measure to mitigate inorganic particulate matter (PM) emissions during small-scale combustion of solid biofuels. Biomass Conv. Bioref. 2019, 9, 3-20. [CrossRef]

34. Fournel, S.; Palacios, J.; Godbout, S.; Heitz, M. Effect of Additives and Fuel Blending on Emissions and Ash-Related Problems from Small-Scale Combustion of Reed Canary Grass. Agriculture 2015, 5, 561-576. [CrossRef]

35. Mediavilla, I.; Fernández, M.J.; Esteban, L.S. Optimization of pelletisation and combustion in a boiler of $17.5 \mathrm{kWth}$ for vine shoots and industrial cork residue. Fuel Process. Technol. 2009, 90, 621-628. [CrossRef]

36. Miranda, M.T.; Arranz, J.I.; Román, S.; Rojas, S.; Montero, I.; López, M.; Cruz, J.A. Characterization of grape pomace and pyrenean oak pellets. Fuel Process. Technol. 2011, 92, 278-283. [CrossRef] 
37. Kallio, M.; Oravainen, H. Agrofuels-Challenging Fuel for the Future. Mix. Proj. 2011, $2011,253-260$.

38. Zeng, T.; Mlonka-Mędrala, A.; Lenz, V.; Nelles, M. Evaluation of bottom ash slagging risk during combustion of herbaceous and woody biomass fuels in a small-scale boiler by principal component analysis. Biomass Conv. Bioref. 2019, 1-19. [CrossRef]

39. Nunes, L.; Matias, J.; Catalao, J.; Nunes, L.; Catalão, J. Mixed biomass pellets for thermal energy production-A review of combustion models//Mixed biomass pellets for thermal energy production: A review of combustion models. Appl. Energy 2014, 127, 135-140. [CrossRef]

40. Höfer, I.; Kaltschmitt, M. Effect of additives on particulate matter formation of solid biofuel blends from wood and straw. Biomass Conv. Bioref. 2017, 7, 101-116. [CrossRef]

41. Schmitt, V. Dissertation am Institut für Umwelttechnik und Energiewirtschaft an der Technischen Universität Hamburg-Harburg; Kovac: Hamburg, Germany, 2013.

42. Carroll, J.P.; Finnan, J.M. The use of additives and fuel blending to reduce emissions from the combustion of agricultural fuels in small scale boilers. Biosyst. Eng. 2015, 129, 127-133. [CrossRef]

43. Lundholm, K.; Nordin, A.; Öhman, M.; Boström, D. Reduced Bed Agglomeration by Co-combustion Biomass with Peat Fuels in a Fluidized Bed. Energy Fuels 2005, 19, 2273-2278. [CrossRef]

44. Wang, Y.; Liu, Y.; Yang, W.; Zhao, Q.; Dai, Y. Evaluation of combustion properties and pollutant emission characteristics of blends of sewage sludge and biomass. Sci. Total Environ. 2020, 720, 137365. [CrossRef] [PubMed]

45. Hülsmann, T. Feinstaubemissionen bei der Verbrennung von Holz-und Holz/Stroh-MIschpellets -Einfluss Einder Brennstoffadditivierung; Technische Universität Hamburg: Hamburg, Germany, 2018.

46. Zeng, T.; Weller, N.; Pollex, A.; Lenz, V. Blended biomass pellets as fuel for small scale combustion appliances: Influence on gaseous and total particulate matter emissions and applicability of fuel indices. Fuel 2016, 184, 689-700. [CrossRef]

47. Meng, X.; Zhou, W.; Yan, Y.; Ren, X.; Ismail, T.M.; Sun, R. Effects of preheating primary air and fuel size on the combustion characteristics of blended pinewood and corn straw in a fixed bed. Energy 2020, 210, 118481. [CrossRef]

48. Örberg, H.; Jansson, S.; Kalén, G.; Thyrel, M.; Xiong, S. Combustion and Slagging Behavior of Biomass Pellets Using a Burner Cup Developed for Ash-Rich Fuels. Energy Fuels 2014, 28, 1103-1110. [CrossRef]

49. Jiang, L.; Yuan, X.; Xiao, Z.; Liang, J.; Li, H.; Cao, L.; Wang, H.; Chen, X.; Zeng, G. A comparative study of biomass pellet and biomass-sludge mixed pellet: Energy input and pellet properties. Energy Convers. Manag. 2016, 126, 509-515. [CrossRef]

50. Wzorek, M.; Junga, R.; Yilmaz, E.; Niemiec, P. Combustion behavior and mechanical properties of pellets derived from blends of animal manure and lignocellulosic biomass. J. Environ. Manag. 2021, 290, 112487. [CrossRef] [PubMed]

51. Boman, C.; Boström, D.; Öhman, M. (Eds.) Effect of Fuel Additive Sorbents (Kaolin and Calcite) on Aerosol Particle Emissions and Characteristics During Combustion of Pelletized Wood Biomass. In Proceedings of the European Biomass Conference, Valensia, Spain, 2-6 June 2008.

52. Schmitt, V.; Kaltschmitt, M. Effect of straw proportion and Ca- and Al-containing additives on ash composition and sintering of wood-straw pellets. Fuel 2013, 109, 551-558. [CrossRef]

53. Brunner, T.; Obernberger, I.; Boman, C.; Rebbing, A.; Mack, R.; Hartmann, H. Guidelines for Advanced Fuel and Boiler Design; BIOS BIOENERGIESYSTEME GmbH: Graz, Austria, 2019.

54. Meng, X.; Sun, R.; Ismail, T.M.; Zhou, W.; Ren, X.; Zhang, R. Parametric studies on corn straw combustion characteristics in a fixed bed: Ash and moisture content. Energy 2018, 158, 192-203. [CrossRef]

55. Dragutinovic, N.; Höfer, I.; Kaltschmitt, M. Joint examination of fuel-related measures for the improvement of corn cob combustion properties. J. Renew. Sustain. Energy 2021, 13. [CrossRef]

56. Ye, Y.; Jiang, W.; Wang, H.; An, X. A New Method for Calculating Excess Air Ratio. In Frontier Computing; Hung, J.C., Yen, N.Y., Hui, L., Eds.; Springer: Singapore, 2019; pp. 767-776. ISBN 978-981-13-3647-8.

57. Paniagua, S.; Prado-Guerra, A.; Neto, A.I.; Nunes, T.; Tarelho, L.; Alves, C.; Calvo, L.F. Influence of Varieties and Organic Fertilizer in the Elaboration of a New Poplar-Straw Pellet and Its Emissions in a Domestic Boiler. Energies 2020, 13, 6332. [CrossRef]

58. Juszczak, M.; Lossy, K. Pollutant emission from a heat station supplied with agriculture biomass and wood pellet mixture. Chem. Process. Eng. 2012, 33, 231-242. [CrossRef]

59. Roy, M.M.; Corscadden, K.W. An experimental study of combustion and emissions of biomass briquettes in a domestic wood stove. Appl. Energy 2012, 99, 206-212. [CrossRef]

60. Bäfver, L.S.; Leckner, B.; Tullin, C.; Berntsen, M. Particle emissions from pellets stoves and modern and old-type wood stoves. Biomass Bioenergy 2011, 35, 3648-3655. [CrossRef]

61. Yao, X.; Xu, K. Comparative study of characterization and utilization of corncob ashes from gasification process and combustion process. Constr. Build. Mater. 2016, 119, 215-222. [CrossRef]

62. Mack, R.; Kuptz, D.; Schön, C.; Hartmann, H. Schwierige Pelletbrennstoffe für Kleinfeuerungsanlagen: Verbrennungstechnische Optimierung durch Additivierung und Mischung; Technologie- und Förderzentrum im Kompetenzzentrum für Nachwachsende Rohstoffe (TFZ): Straubing, Germany, 2020.

63. Schmidl, C.; Luisser, M.; Padouvas, E.; Lasselsberger, L.; Rzaca, M.; Ramirez-Santa Cruz, C.; Handler, M.; Peng, G.; Bauer, H.; Puxbaum, H. Particulate and gaseous emissions from manually and automatically fired small scale combustion systems. Atmos. Environ. 2011, 45, 7443-7454. [CrossRef]

64. Verma, V.K.; Bram, S.; Delattin, F.; Laha, P.; Vandendael, I.; Hubin, A.; de Ruyck, J. Agro-pellets for domestic heating boilers: Standard laboratory and real life performance. Applied Energy 2012, 90, 17-23. [CrossRef] 
65. Krugly, E.; Martuzevicius, D.; Puida, E.; Buinevicius, K.; Stasiulaitiene, I.; Radziuniene, I.; Minikauskas, A.; Kliucininkas, L. Characterization of Gaseous- and Particle-Phase Emissions from the Combustion of Biomass-Residue-Derived Fuels in a Small Residential Boiler. Energy Fuels 2014, 28, 5057-5066. [CrossRef]

66. He, Y.; Tang, S.; Yin, S.; Li, S. Research progress on green synthesis of various high-purity zeolites from natural material-kaolin. J. Clean. Prod. 2021, 306, 127248. [CrossRef]

67. Ye, N.; Li, Y.; Yang, Z.; Zheng, J.; Zuo, S. Rare earth modified kaolin-based Cr2O3 catalysts for catalytic combustion of chlorobenzene. Appl. Catal. A Gen. 2019, 579, 44-51. [CrossRef]

68. Cheng, W.; Zhu, Y.; Shao, J.; Zhang, W.; Wu, G.; Jiang, H.; Hu, J.; Huang, Z.; Yang, H.; Chen, H. Mitigation of ultrafine particulate matter emission from agricultural biomass pellet combustion by the additive of phosphoric acid modified kaolin. Renew. Energy 2021, 172, 177-187. [CrossRef]

69. Jeguirim, M.; Kraiem, N.; Lajili, M.; Guizani, C.; Zorpas, A.; Leva, Y.; Michelin, L.; Josien, L.; Limousy, L. The relationship between mineral contents, particle matter and bottom ash distribution during pellet combustion: Molar balance and chemometric analysis. Environ. Sci. Pollut. Res. Int. 2017, 24, 9927-9939. [CrossRef] [PubMed]

70. Nussbaumer, T. Aerosols from Biomass Combustion: Technical report on behalf of the IEA Bioenergy Task 32; IEA Bioenergy: Zurich, Switzerland, 2017.

71. Gollmer, C.; Höfer, I.; Kaltschmitt, M. Laboratory-scale additive content assessment for aluminum-silicate-based wood chip additivation. Renew. Energy 2021, 164, 1471-1484. [CrossRef]

72. Johansson, L.S.; Tullin, C.; Leckner, B.; Sjövall, P. Particle emissions from biomass combustion in small combustors. Biomass Bioenergy 2003, 25, 435-446. [CrossRef]

73. Tissari, J.; Sippula, O.; Kouki, J.; Vuorio, K.; Jokiniemi, J. Fine Particle and Gas Emissions from the Combustion of Agricultural Fuels Fired in a $20 \mathrm{~kW}$ Burner. Energy Fuels 2008, 22, 2033-2042. [CrossRef]

74. Gollmer, C.; Höfer, I.; Harms, D.; Kaltschmitt, M. Potential additives for small-scale wood chip combustion—Laboratory-scale estimation of the possible inorganic particulate matter reduction potential. Fuel 2019, 254, 115695. [CrossRef]

75. Míguez, J.L.; Porteiro, J.; Behrendt, F.; Blanco, D.; Patiño, D.; Dieguez-Alonso, A. Review of the use of additives to mitigate operational problems associated with the combustion of biomass with high content in ash-forming species. Renew. Sustain. Energy Rev. 2021, 141, 110502. [CrossRef]

76. Llorente, M.F.; Arocas, P.D.; Nebot, L.G.; García, J.C. The effect of the addition of chemical materials on the sintering of biomass ash. Fuel 2008, 87, 2651-2658. [CrossRef]

77. PubChem. Potassium Carbonate. Available online: https://pubchem.ncbi.nlm.nih.gov/compound/Potassium-carbonate (accessed on 1 June 2021).

78. PubChem. Calcium Carbonate. Available online: https://pubchem.ncbi.nlm.nih.gov/compound/Calcium-carbonate (accessed on 1 June 2021).

79. Misra, M.K.; Ragland, K.W.; Baker, A.J. Wood ash composition as a function of furnace temperature. Biomass Bioenergy 1993, 4 103-116. [CrossRef]

80. Demirbas, A. Potential applications of renewable energy sources, biomass combustion problems in boiler power systems and combustion related environmental issues. Prog. Energy Combust. Sci. 2005, 31, 171-192. [CrossRef]

81. Demirbas, A. Combustion characteristics of different biomass fuels. Prog. Energy Combust. Sci. 2004, 30, 219-230. [CrossRef]

82. Knudsen, J.N.; Jensen, P.A.; Dam-Johansen, K. Transformation and Release to the Gas Phase of $\mathrm{Cl}$, $\mathrm{K}$, and S during Combustion of Annual Biomass. Energy Fuels 2004, 18, 1385-1399. [CrossRef]

83. Lighty, J.S.; Veranth, J.M.; Sarofim, A.F. Combustion aerosols: Factors governing their size and composition and implications to human health. J. Air Waste Manag. Assoc. 2000, 50, 1565-1618; discussion 1619-1622. [CrossRef] [PubMed]

84. Höfer, I.; Gollmer, C.; Kaltschmitt, M. Inorganic PM and K emissions during ashing of solid biofuels and Kaolinite-Data measurement in laboratory scale. Fuel 2021, 296, 120704. [CrossRef]

85. Zhu, Y.; Chen, Y.; Cheng, W.; Zhang, W.; Hu, J.; Zeng, K.; Yang, H.; Shao, J.; Chen, H. Reduction of fine particulate matter emissions from cornstalk combustion by calcium phosphates additives. Fuel 2021, 283, 119303. [CrossRef]

86. Johansen, J.M.; Jakobsen, J.G.; Frandsen, F.J.; Glarborg, P. Release of K, Cl, and S during Pyrolysis and Combustion of HighChlorine Biomass. Energy Fuels 2011, 25, 4961-4971. [CrossRef]

87. Jin, X.; Ye, J.; Deng, L.; Che, D. Condensation Behaviors of Potassium during Biomass Combustion. Energy Fuels 2017, 31, 2951-2958. [CrossRef]

88. Sippula, O.; Hokkinen, J.; Puustinen, H.; Yli-Pirilä, P.; Jokiniemi, J. Particle Emissions from Small Wood-fired District Heating Units. Energy Fuels 2009, 23, 2974-2982. [CrossRef]

89. Boman, C.; Nordin, A.; Boström, D.; Öhman, M. Characterization of Inorganic Particulate Matter from Residential Combustion of Pelletized Biomass Fuels. Energy Fuels 2004, 18, 338-348. [CrossRef]

90. Strand, M.; Lillieblad, L.; Sanati, M.; Pagels, J.; Szpila, A.; Boghard, M.; Rissler, J.; Swietlicki, E. Aerosol Formation and Effect in Biomass Combustion and Gasification; Report nr 2/2005; Vaxjo University: Vaxjo, Sweden, 2005.

91. Du, S.; Yang, H.; Qian, K.; Wang, X.; Chen, H. Fusion and transformation properties of the inorganic components in biomass ash. Fuel 2014, 117, 1281-1287. [CrossRef] 